LA-14233

Approved for public release;

distribution is unlimited.

\title{
U.S. DOE 2004 LANL Radionuclide
}

\section{Air Emissions}

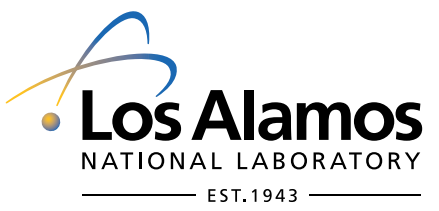

The World's Greatest Science Protecting America 
This report was funded by the U.S. Department of Energy.

Los Alamos National Laboratory, an affirmative action/ equal opportunity employer, is operated by the University of California for the United States Department of Energy under contract W-7405-ENG-36.

This report was prepared as an account of work sponsored by an agency of the United States Government. Neither the Regents of the University of California, the United States Government nor any agency thereof, nor any of their employees make any warranty, express or implied, or assume any legal liability or responsibility for the accuracy, completeness, or usefulness of any information, apparatus, product, or process disclosed, or represent that its use would not infringe privately

owned rights. Reference herein to any specific commercial product, process, or service by trade name, trademark, manufacturer, or otherwise does not necessarily constitute or imply its endorsement, recommendation, or favoring by the Regents of the University of California, the United States Government, or any agency thereof. The views and opinions of authors expressed herein do not necessarily state or reflect those of the Regents of the University of California, the United States Government, or any agency thereof. Los Alamos National Laboratory strongly supports academic freedom and a researcher's right to publish; as an institution, however, the Laboratory does not endorse the viewpoint of a publication or guarantee its technical correctness. 
LA-14233

Issued: August 2005

\title{
U.S. DOE 2004 LANL Radionuclide
}

Air Emissions

\author{
Keith W. Jacobson \\ David P. Fuehne
}





\section{Contents}

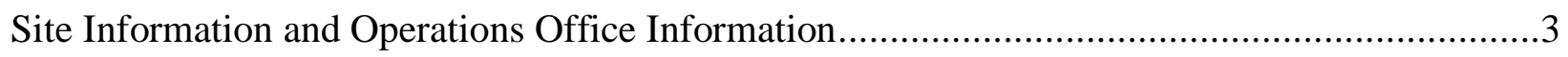

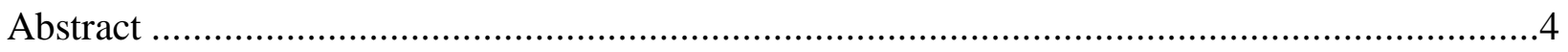

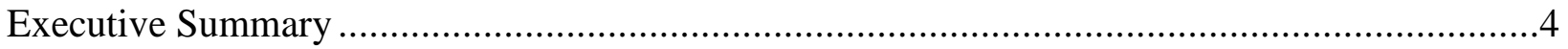

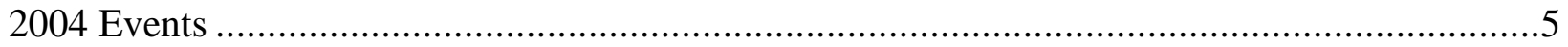

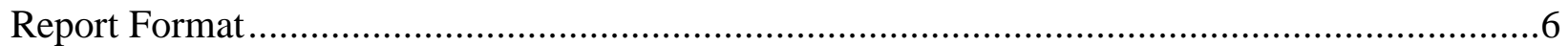

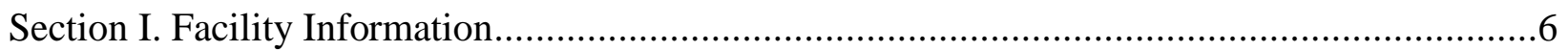

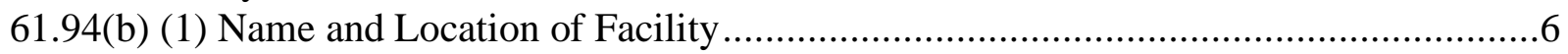

61.94(b) (2) List of Radioactive Materials Used at LANL .....................................................6

61.94(b) (3) Handling and Processing of Radioactive Materials at LANL Technical Areas......7

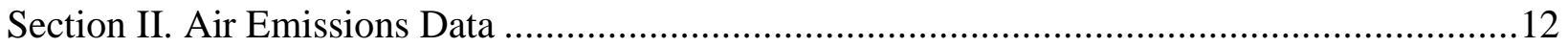

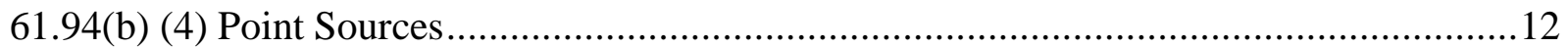

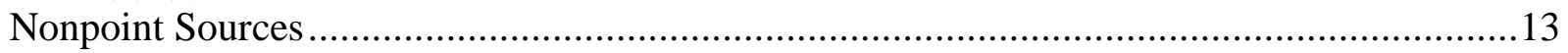

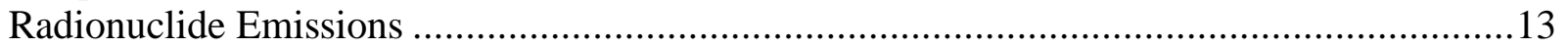

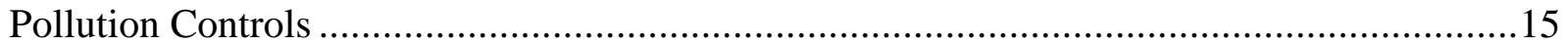

Compliance with New Maintenance and Inspection Requirements under the Revised

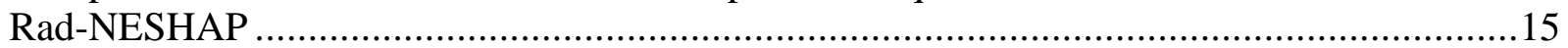

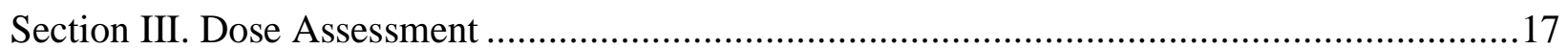

61.94(b) (7) Description of Dose Calculations ..................................................................17

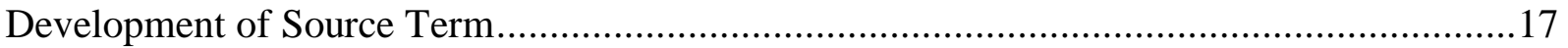

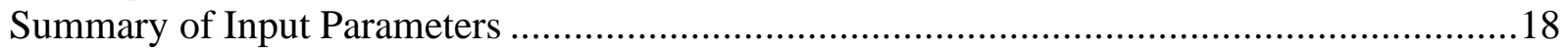

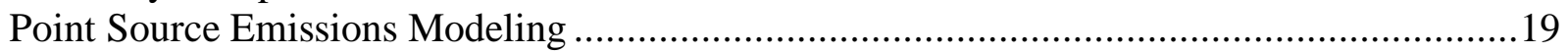

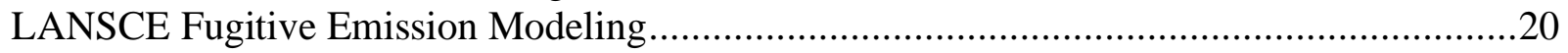

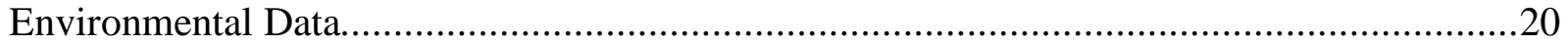

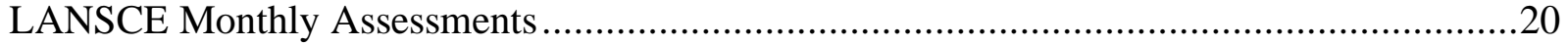

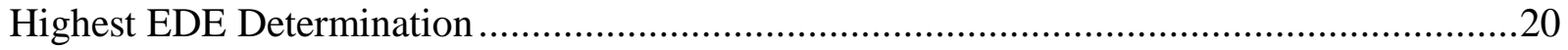

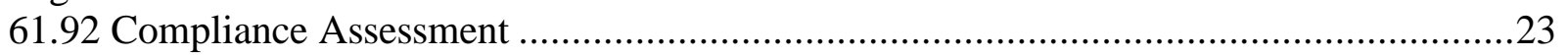

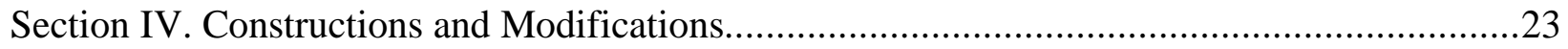

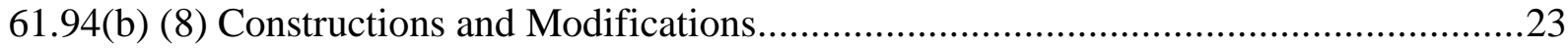

Ultra-Cold Neutron Target and Moderator System ……..................................................23

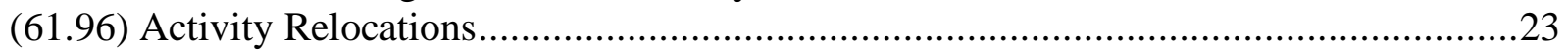

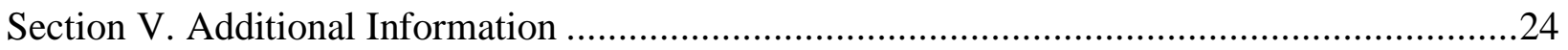

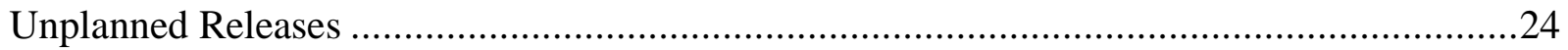

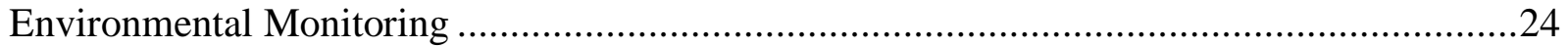

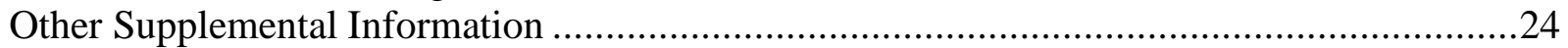

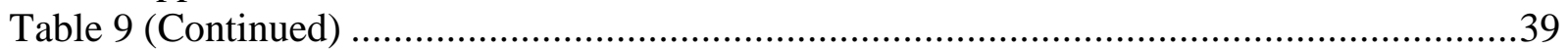

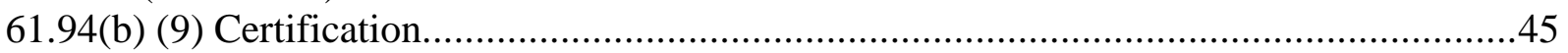




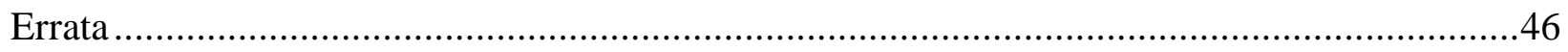

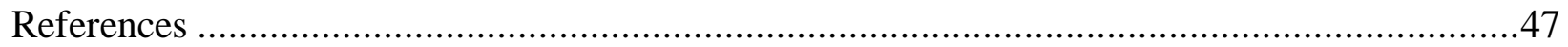




\title{
Site Information and Operations Office Information
}

\author{
U.S. Department of Energy Report \\ 2004 LANL Radionuclide Air Emissions
}

$\begin{array}{ll}\text { Site Name: } & \text { Los Alamos National Laboratory } \\ \text { Location: } & \text { County of Los Alamos, New Mexico }\end{array}$

Operations Office Information:

\author{
Office: Los Alamos Site Office \\ Address: $\quad$ U.S. Department of Energy \\ National Nuclear Security Administration \\ Los Alamos Site Office \\ Los Alamos, NM 87544 \\ Contact: John Ordaz Phone: (505) 665-6351
}

Site Information:
Operator: University of California
Address: $\quad$ Los Alamos National Laboratory
PO Box 1663
Los Alamos, NM 87545
Contact: David Fuehne Phone: (505) 665-8855

Compliance Assessment:

2004 EDE: 1.68 mrem 


\begin{abstract}
Amendments to the Clean Air Act, which added radionuclides to the National Emissions Standards for Hazardous Air Pollutants (NESHAP), went into effect in 1990. Specifically, a subpart (H) of 40 CFR 61 established an annual limit on the impact to the public attributable to emissions of radionuclides from U.S. Department of Energy facilities, such as the Los Alamos National Laboratory (LANL). As part of the new NESHAP regulations, LANL must submit an annual report to the U.S. Environmental Protection Agency headquarters and the regional office in Dallas by June 30. This report includes results of monitoring at LANL and the dose calculations for the calendar year 2004.
\end{abstract}

\title{
Executive Summary
}

Presented is the Los Alamos National Laboratory (LANL)-wide certified report regarding radioactive effluents released into the air by LANL in 2004. This report fulfills the requirements established by the Radionuclide National Emission Standard for Hazardous Air Pollutants (Rad-NESHAP). The Rad-NESHAP section of LANL's Meteorology and Air Quality Group (MAQ) prepared this report. This information is required under the Clean Air Act and is being reported to the U.S. Environmental Protection Agency (EPA). The highest effective dose equivalent (EDE) to an off-site member of the public was calculated using procedures specified by the U.S. EPA and described in this report. LANL's EDE was 1.68 mrem for 2004. The annual limit established by the EPA is 10 mrem per year.

To comply with the Rad-NESHAP regulation, LANL monitors radionuclide emissions at 28 release points, or stacks. Also, the MAQ group uses a network of air samplers around LANL to monitor airborne levels of radionuclides. In addition, LANL maintains and operates meteorological monitoring systems.

The EDE is evaluated at any member of the public at any off-site location where there is a residence, school, business, or office. In 2004, this location was a business located at East Gate Drive on the northeastern boundary of LANL. The majority of this dose is due to airborne effluents from a linear particle accelerator located at the Los Alamos Neutron Science Center (LANSCE) near the northeastern boundary of LANL. Doses reported to the U.S. EPA for the past nine years are shown in Table E1. 
2004 LANL Radionuclide Air Emissions Report

In 2004, LANSCE operated in the same configuration as 2003, with beam operations to the 1L Target and the Lujan Neutron Scattering Center and other lower-level beam experimental areas. The facility operated with the beam on from January to May of 2004. Similar to previous years, LANSCE contributed approximately $90 \%$ of the total offsite dose from LANL operations. In 2004, the contribution was about $91 \%$ of the total value. The higher emissions in 2004 are due to operations requiring higher beam power and increased radioactive gas production occurring in the water used to cool the $1 \mathrm{~L}$ Target.

Table E1. Ten-Year Summary of NESHAP's Dose Assessment for LANL

\begin{tabular}{|c|c|l|}
\hline Year & EDE (mrem) & Highest EDE Location \\
\hline 1995 & 5.05 & 2470 East Gate Dr \\
\hline 1996 & 1.93 & 2470 East Gate Dr \\
\hline 1997 & 3.51 & 2470 East Gate Dr \\
\hline 1998 & 1.72 & 2470 East Gate Dr \\
\hline 1999 & 0.32 & County Landfill Office \\
\hline 2000 & 0.64 & 2470 East Gate Dr \\
\hline 2001 & 1.84 & 2470 East Gate Dr \\
\hline 2002 & 1.69 & 2470 East Gate Dr \\
\hline 2003 & 0.65 & 2470 East Gate Dr \\
\hline 2004 & 1.68 & 2470 East Gate Dr \\
\hline
\end{tabular}

\section{Events}

In early January of 2004, a new Isotope Production Facility (IPF) was dedicated at LANSCE. The IPF will produce radioisotopes for medical research and a variety of development and research applications. We calculated the air emissions from this new facility and included those emission results in this report. As a non-point emissions source, the projected emissions during the project planning did not require continuous monitoring. The 2004 emission measurements for this source have verified the low-level effluents from the IPF.

Also in January, the MAQ Group determined that an upcoming operation at Technical Area 54 (TA-54) will require additional stack monitoring. The operation is known as the Decontamination and Volume Reduction System, located at TA-54 building 412. The MAQ group has been identifying sample equipment and performing stack tests to characterize the sampling location. The sampling system was installed in spring 2005 and the facility is expected to become operational in the summer of 2005. A courtesy memo was sent to EPA on May 25, 2005 (memo ENVMAQ:05-146).

A series of incidents in early July led the LANL director to suspend all normal operating activities until all members of the work force could ensure that the LANL could operate safely while meeting its national security obligations. However, activities that ensure regulatory compliance, such as stack monitoring and air sampling, were allowed to continue uninterrupted during the LANL-wide shut down. As a result of this shut down, operations were reduced for 2004 in several areas, resulting in lower-than-expected emissions for many facilities. 


\section{LANL Radionuclide Air Emissions Report}

In December, an external audit of the Rad-NESHAP program was undertaken. Subject matter experts from other DOE facilities that operate Rad-NESHAP programs were selected to perform the audit, with a certified auditor providing the lead for the effort. Four areas were examined: (1) a review of actions taken in response to the 2002 external audit by Risk Assessment Corporation; (2) a review of LANL's compliance with the 2003 changes to the Rad-NESHAP regulations; (3) a review of data handling from sample exchange to report preparation; and (4) a general overview of the program to ensure all pieces are in place to meet federal regulations. As a result of this audit, several observations were made and corrective actions taken.

\section{Report Format}

This report contains two major divisions. The first division primarily describes the Rad-NESHAP program and compliance activities at LANL and is organized into five sections. The second division consists mainly of data tables required for reporting purposes; in this section, Table 14 provides doses calculated at various public locations around LANL. Table 15 summarizes the different LANL contributions to the total highest dose for the calendar year 2004.

\section{Section I. Facility Information}

\subsection{4(b) (1) Name and Location of Facility}

Los Alamos National Laboratory (LANL, or the Laboratory) and the associated residential areas of Los Alamos and White Rock are located in Los Alamos County, in north-central New Mexico, approximately 100 km (60 mi.) northnortheast of Albuquerque and 40 km (25 mi.) northwest of Santa Fe (Figure 1).

\subsection{4(b) (2) List of Radioactive Materials Used at LANL}

Since the Laboratory's inception in 1943, its primary mission has been nuclear weapons research and development. Programs include weapons development, nonproliferation, magnetic and inertial fusion, nuclear fission, nuclear safeguards and security, and laser isotope separation. There is also basic research in the areas of physics, chemistry, and engineering, and in biology that complements and draws upon basic research in the physical sciences.

The primary facilities involved in the emissions of radioactivity are outlined in this section. The facility locations are designated by technical area (TA) and building. For example, the facility designation TA-3-29 is Building 29 at Technical Area 3 (see Figure 2 showing the technical areas at LANL). Potential radionuclide release points are listed in several tables that follow. Some of the sources described below are characterized as nonpoint. Beginning in 1995, air sampling results from LANL's air sampling network (AIRNET) were used, with EPA approval, to calculate offsite impacts resulting from diffuse and fugitive emissions of radioactive particles and tritium oxide from nonpoint sources. 


\section{LANL Radionuclide Air Emissions Report}

Radioactive materials used at LANL include weapons-grade plutonium, heat-source plutonium, enriched uranium, depleted uranium, and tritium. Also, a variety of materials are generated through the process of activation;

consequent emissions occur as gaseous mixed activation products (GMAP) and other activation products occur in particulate and vapor form (P/VAP).

The radionuclides emitted from point sources at LANL in CY 2004 are listed in the subsequent tables. Tritium is released as tritium oxide and elemental tritium. Plutonium contains traces of ${ }^{241} \mathrm{Am}$, a transformation product of ${ }^{241} \mathrm{Pu}$. Some of the uranium emissions are from open-air explosive tests involving depleted uranium. GMAP emissions include ${ }^{41} \mathrm{Ar},{ }^{11} \mathrm{C},{ }^{13} \mathrm{~N},{ }^{16} \mathrm{~N},{ }^{14} \mathrm{O}$, and ${ }^{15} \mathrm{O}$. Various radionuclides such as ${ }^{197 \mathrm{~m}} \mathrm{Hg},{ }^{197} \mathrm{Hg},{ }^{68} \mathrm{Ge}$, and ${ }^{76} \mathrm{Br}$ make up the majority of the P/VAP emissions.

\subsection{4(b) (3) Handling and Processing of Radioactive Materials at LANL Technical Areas}

Additional descriptions of LANL technical areas can be found in the annual environmental report for LANL. More thorough descriptions of LANL operations can be found in the annual yearbooks published by LANL's Site-Wide Issues Program Office, the most recent being published in $2004 .^{1}$ 


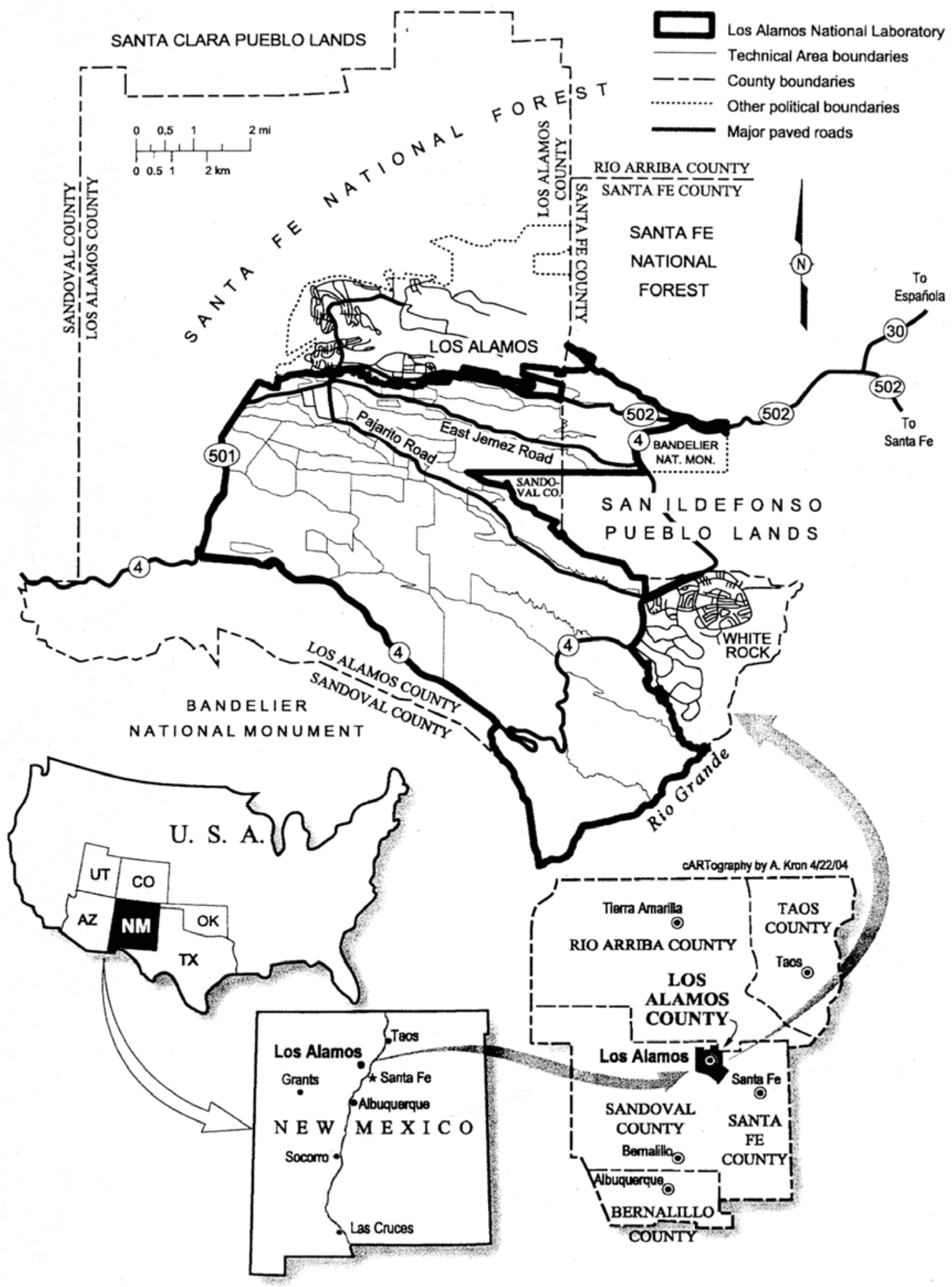

Figure 1. Location of Los Alamos National Laboratory. 


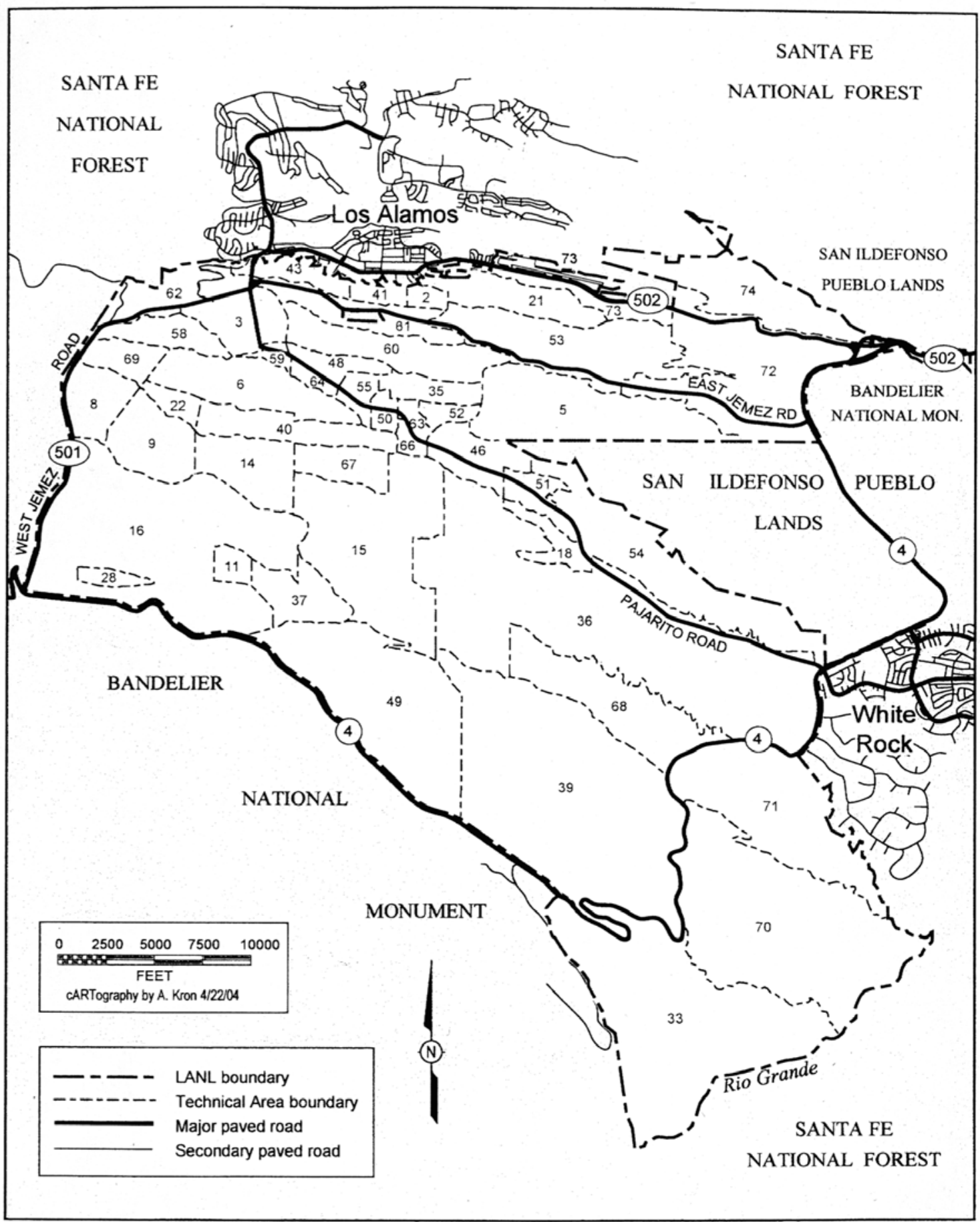

Figure 2. Los Alamos National Laboratory technical areas by number. 


\section{LANL Radionuclide Air Emissions Report}

The primary facilities responsible for radiological airborne emissions are as follows.

TA-3-29: The Chemistry and Metallurgy Research (CMR) facility conducts chemical and metallurgical research. The principal radionuclides used are isotopes of plutonium as well as other actinides. There are a variety of activities involving plutonium and uranium, which support many LANL and other DOE programs conducted primarily at other facilities.

TA-3-66: This building and three other main buildings are used for a variety of nuclear materials work, primarily for dealing with metallic and ceramic items, including depleted uranium.

TA-3-102: This machine shop is used for the metalworking of radioactive materials, primarily depleted uranium.

TA-3-1698: This facility is designated as the Materials Science Laboratory. The building was designed to accommodate a wide variety of chemicals used in small amounts that are typical of many university and industrial labs conducting research in materials science.

TA-15 and TA-36: These facilities conduct open-air explosive tests involving depleted uranium and weapons development testing.

TA-15-312-DARHT: This facility conducts high-explosive-driven experiments to investigate weapons functions and behavior during non-nuclear tests using advanced radiography. The facility completed the construction of the second stage of the flash X-ray machine in March 2003.

TA-16-205-WETF: This facility is located in Buildings 205 and 205A in the southeast section of TA-16.

Building 205 was specifically designed and built to process tritium safely and to meet user needs and specifications. The operations at WETF are divided into two categories: tritium processing and activities that support tritium processing. Examples of tritium-processing operations include the repackaging of tritium into smaller quantities and the packaging of tritium and other gases to user-specified pressures. Other operations include reacting tritium with other materials to form compounds and analyzing the effects of tritium.

TA-21: Many of the facilities at this decommissioned radiochemistry site are undergoing decontamination and demolition (D\&D). Some of these operations may contribute to diffuse emissions of uranium and plutonium into the air. The DP West area has been in the D\&D program since 1992; a number of buildings have been demolished.

TA-21-155 and TA-21-209: These facilities, located in the DP East area, previously conducted operations involving tritium. Programs included the testing of tritium-control systems for the nuclear fusion program (TA-21-155), the preparation of targets containing tritium for laser-fusion research, and the handling of tritium for defense programs. Building 155 is being prepared for D\&D in the near future. Tritium recovery operations from old equipment are being conducted at TA-21-209. 


\section{LANL Radionuclide Air Emissions Report}

TA-18: This nuclear facility studies the behavior of nuclear materials using critical assemblies. Some of the assemblies are used as a source of fission neutrons for experimental purposes, resulting in a diffuse source of ${ }^{41} \mathrm{Ar}$ emissions.

TA-41-4: This building was formerly used as a tritium-handling facility. The tritium sources were removed in 2002. Emissions primarily result from residual tritium contamination and cleanup operations.

TA-48-1: The principal activities carried out in this facility are radiochemical separations supporting the medical radioisotope production program, the Yucca Mountain program, nuclear chemistry experiments, and geochemical and environmental research. These separations involve $\mathrm{nCi}$ to $\mathrm{Ci}$ (hot cell) amounts of radioactive materials and use a wide range of analytical chemical separation techniques, such as ion exchange, solvent extraction, mass spectroscopy, plasma emission spectroscopy, and ion chromatography.

TA-50-1: This waste management site consists of an industrial low-level (radioactive) liquid waste treatment plant. There is a wastewater outfall from TA-50-1 that may result in a diffuse source of airborne tritium.

TA-50-37: Currently there are no operations involving radioactive material in this building, future operations may involve the use of radioactive actinides.

TA-50-69: This waste management site consists of a waste characterization, reduction, and repackaging facility.

TA-53: This technical area houses the Los Alamos Neutron Science Center (LANSCE), a linear particle accelerator complex. The accelerator is used to conduct research in stockpile stewardship, radiobiology, materials science, and isotope production, among other areas. LANSCE consists of the Manuel Lujan Neutron Scattering Center, the Proton Storage Ring, the Weapons Neutron Research facilities, the Proton Radiography facility, and the highintensity beam line (Line A).

The facility accelerates protons and $\mathrm{H}^{-}$ions to an energy of $800 \mathrm{MeV}$ into target materials such as graphite and tungsten to produce neutrons and other subatomic particles. The design current of the accelerator is approximately 1000 microamperes. Medium (100 micro amp) intensity beam operations to the Proton Storage Ring (PSR) and the Manuel Lujan Neutron Scattering Center were conducted in January through April 2004. Low-intensity beam (up to 10 microamps) operations to the PSR, the Weapons Neutron Research facility, and the Proton Radiography facility were conducted throughout the same period.

Airborne radioactive emissions result from proton beams and secondary particles passing through and activating air in target cells, beam stop, and surrounding areas, or activating water used in target cooling systems. The majority of the emissions are short-lived activation products such as ${ }^{11} \mathrm{C},{ }^{13} \mathrm{~N}$, and ${ }^{15} \mathrm{O}$. Most of the activated air is vented through the main stacks; however, a fraction of the activated air becomes a fugitive emission from the target areas. Two solar evaporative basins were constructed and began operation in 1999 to evaporate wastewater from the accelerator. Evaporation of water from these facilities can result in a diffuse source of airborne tritium. 


\section{LANL Radionuclide Air Emissions Report}

TA-54: This waste management site consists of active and inactive shallow land burial sites for solid waste and is the primary storage area for mixed and transuranic radioactive waste. Area G at TA-54 is a known source of diffuse emissions of tritium vapor. Resuspension of soil contaminated with low levels of plutonium/americium has also created a diffuse source. Shipments of transuranic waste for disposal at the Waste Isolation Pilot Plant began in 1999.

TA-55-4: As discussed in the Site-Wide Environmental Impact Statement for Continued Operation of the Los Alamos National Laboratory, this facility is slated for a plutonium pit production mission while it continues its traditional role of housing research-and-development applications in chemical and metallurgical processes for recovering, purifying, and converting plutonium and other actinides. ${ }^{2}$ A wide range of activities (e.g., the heating, dissolution, forming, welding, etc., of special nuclear materials) is also conducted. Additional activities include the investigating the means to safely ship, receive, handle, and store nuclear materials, and manage wastes and residues from TA-55.

\section{Section II. Air Emissions Data}

\subsection{4(b) (4) Point Sources}

Monitored and unmonitored exhaust stacks or point sources at LANL are listed in Table 1. The point sources are identified using an eight-digit identification number for each exhaust stack (ESIDNUM); the first two digits represent the LANL technical area, the next four the building, and the last two digits the stack number. Also listed in Table 1 are type, number, and efficiency of the effluent controls used on the release points. Each stage of the highefficiency particulate air (HEPA) exhaust filters is tested at least once every 12 months. The performance criteria for HEPA filter systems are a maximum penetration of $5 \times 10^{-4}$ for one stage and $2.5 \times 10^{-7}$ for two stages in series, in which penetration equals the concentration of aerosol downstream of the air cleaner divided by concentration upstream.

The distance between each of the 28 monitored point sources and the nearest receptor is provided in Table 2 . The nearest receptor can be a residence, school, business, or office. In this report, the nearest receptor is defined as the public receptor most impacted by a given release point; that is, the air dispersion pattern is taken into account to determine the nearest or most critical receptor location. The distance to the nearest farm producing milk is $20 \mathrm{~km}$ east of the Laboratory's eastern boundary; the nearest farms producing meat and vegetables adjoin the Laboratory's eastern boundary, about $4 \mathrm{~km}$ from the main exhaust stack at LANSCE. More detailed agricultural information can be found in a supplemental LANL report ${ }^{3}$. At this time, LANL is not using this site-specific agricultural data in the CAP88 model; preprogrammed or default values for New Mexico are utilized for the number of beef and milk cattle and for agricultural productivity.

In addition to the 28 monitored release points, approximately 60 unmonitored release points in more than 30 LANL buildings are included in Table 1. Under 40 CFR 61.93(b) (4)(i), sampling of these release points is not required because each release point has a potential effective dose equivalent (EDE) of less than $0.1 \mathrm{mrem} / \mathrm{yr}$ at the critical 


\section{LANL Radionuclide Air Emissions Report}

receptor. However, in order to verify that emissions from unmonitored point sources remain low, LANL conducts periodic confirmatory measurements in the form of the Radioactive Materials Usage Survey. The purpose of this survey is to collect and analyze radioactive materials usage and process information for the monitored and unmonitored point sources at LANL.

Guided by Appendix D to 40 CFR 61, we have used data collected from the facilities in conjunction with engineering calculations and other methods to develop conservative emissions estimates from unmonitored point sources. Estimated potential effective dose equivalents (PEDEs) are calculated by modeling these emissions estimates using the EPA-approved CAP88 dose modeling software. A comprehensive survey of all of LANL's monitored and unmonitored point sources is conducted annually or biannually, depending on the magnitude of potential emissions. Results of the 2004 Usage Survey can be found in the report 2004 Radioactive Materials Usage Survey for Point Sources. ${ }^{4}$ The Laboratory has established administrative requirements to evaluate all potential new sources. These requirements are established for the review of new Laboratory activities and projects, ensuring that air quality regulatory requirements will be met before the activity or project begins. 5

\section{Nonpoint Sources}

There are a variety of nonpoint sources within the $111 \mathrm{~km}^{2}$ of land occupied by LANL. Nonpoint sources can occur as diffuse or large-area sources or as leaks or fugitive emissions from facilities. Examples of nonpoint sources of airborne radionuclides include surface impoundments, shallow land burial sites, open burn sites, live firing sites, outfalls, container storage areas, unvented buildings, waste-treatment areas, solid waste management units, and tanks. The Laboratory measures the annual average ambient concentrations of important airborne radionuclides (other than activated gases) at a number of potential receptor locations.

Beginning in 1995, LANL began summarizing the potential impacts of nonpoint sources by analyzing and reporting air concentration measurements collected at ambient air-sampling sites around the Laboratory. Previously, LANL had estimated emissions from the most significant nonpoint sources and determined the impacts using EPA's dose assessment computer program. The Laboratory and EPA negotiated this method of assessing nonpoint sources as part of a Federal Facility Compliance Agreement (FFCA) ${ }^{6}$. Results of the air sampling analysis are provided in Section III of this report. There were no unusual results recorded by the air sampling stations for 2004.

\section{Radionuclide Emissions}

Radionuclides released from monitored point sources, along with the annual emissions for each radionuclide, are documented in Table 9. The point sources are identified using an eight-digit identification number for each exhaust stack (ESIDNUM): the first two digits represent the LANL technical area, the next four digits the building and the last two digits the stack number. No detectable emissions are denoted as ND. A map showing the general locations of the facilities continuously monitored for radionuclide emissions is shown in Figure 3. 


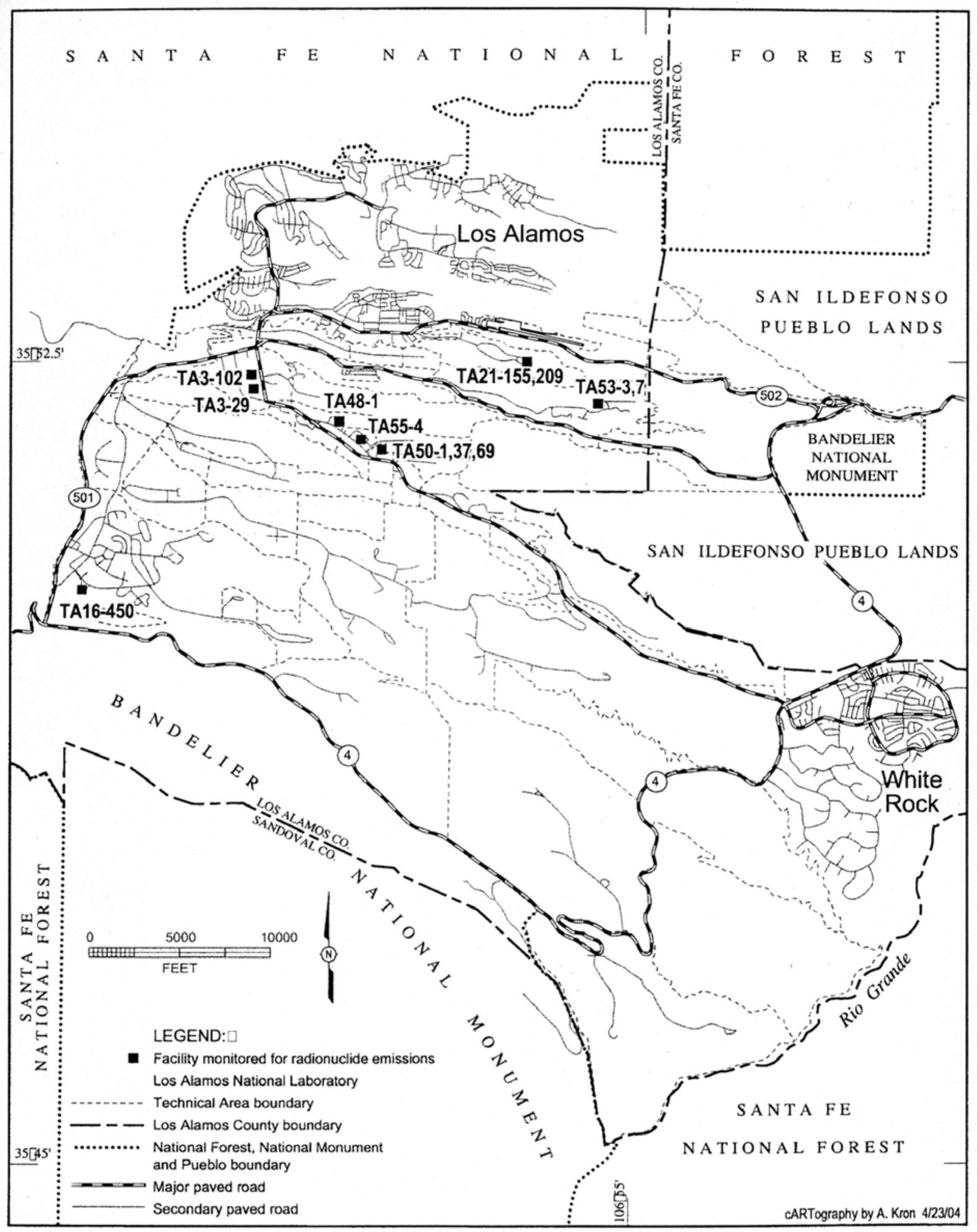

Figure 3. Locations of facilities with continuously operated stack-sampling systems for radionuclide emissions. 


\section{LANL Radionuclide Air Emissions Report}

\section{Pollution Controls}

At Los Alamos National Laboratory the most common type of filtration for emission control purposes is the HEPA filter. HEPA filters are constructed of submicrometer glass fibers that are pressed and glued into a compact, paperlike, pleated media. The media is folded alternately over corrugated separators and mounted into a metal or wood frame in eight standard sizes and airflow capacities. A Type I nuclear-grade HEPA filter is capable of removing 99.97\% of $0.3 \mu \mathrm{m}$ particles at rated airflow. Other types of filters used in ventilation systems are Aerosol 95, RIGAFLOW 220, and FARR 30/30. These units are typically used as prefilters in HEPA filtration systems. These filters are significantly less efficient than HEPA filters and are typically used for collecting particulate matter larger than 5 $\mu \mathrm{m}$. The above-mentioned filters are only effective for particles. When the contaminant of concern is in the form of a gas, activated charcoal beds can be used. Charcoal beds collect the gas contaminant through an adsorption process in which the gas comes in contact with the charcoal and adheres to the surface of the charcoal. The charcoal can be coated with different types of materials to make the adsorption process more efficient for different types of contaminants. Typically, charcoal beds can achieve an efficiency of $98 \%$ capture.

Tritium effluent controls are generally composed of a catalytic reactor and a molecular sieve bed (CR/MS). Tritiumcontaminated effluent is passed through a catalyst that converts elemental tritium (HT) into tritium oxide (HTO). This HTO is then collected as water on a molecular sieve bed. This process can be repeated until the tritium level is at, or below, the desired level. The effluent is then vented through the stack.

A delay system is used to reduce some of the short-lived radionuclides generated by activation at LANSCE. Emissions from the highest source of activated gas (the off-gas system for the 1L target cooling loops) are directed into a long transport line to hold up the radionuclide gases prior to their emission. This delay system is used to provide a reduction in radionuclide emissions from the $1 \mathrm{~L}$ target area.

\section{Compliance with New Maintenance and Inspection Requirements under the Revised Rad-NESHAP}

The 2003 revisions to Subpart H established several new inspection and maintenance requirements for monitored stacks. These requirements are based on Table 5 of ANSI/HPS N13.1-1999, "Sampling and Monitoring Releases of Airborne Radioactive Substances from the Stacks and Ducts of Nuclear Facilities."

As mentioned in the 2003 annual report to EPA, LANL's approach to these requirements was three-fold, and included (1) administrative changes to the QA program, (2) visual inspections of systems, and (3) alternative method approval for tritium stacks. Parts (1) and (3) remain unchanged since 2003. For part (2), the visual inspection, an update on the stack inspection process is worthwhile. 


\section{LANL Radionuclide Air Emissions Report}

As stated before, LANL went through an operations stand-down in July, which extended into the fall of 2004 . As a result, the MAQ group had to perform visual inspection of stack sampling systems on an accelerated, compressed schedule. To accomplish this schedule, we documented the inspections with a checklist and logbook-based inspection system, without including the best-practice video and photo image record as had been done in 2003. While this simpler 2004 method met all requirements, we intend to return to including imagery with the 2005 inspection records.

It should be noted that the stacks at the plutonium facility (TA-55) were not inspected in 2004, as they are on a schedule for a planned maintenance upgrade in 2005. For more information on the TA-55 system, please see memo ENV-MAQ:04-340, sent to EPA Region 6 on October 25, 2004. A copy of this letter is on the Web at http://www.airquality.lanl.gov/pdf/NESHAP/LA-UR-04-7516.pdf . For this planned maintenance upgrade, all items are on schedule for completion of the upgrade in October 2005.

There were two stack monitoring systems at the CMR facility (TA-3, Building 29) that were identified as needing cleaning during the 2003 inspections. This schedule was delayed due to the LANL work suspension, but both systems were cleaned in January 2005. The deposition noted in these systems was oil droplets, likely from HVAC system maintenance on these stacks.

In 2004, no radiological material was measured on inspection equipment or cleaning equipment. Therefore, no additions to the source term are required from this pathway for 2004.

The external audit of the Rad-NESHAP program that took place in 2004 had one focus area related to the stack sample system inspection processes. One observation from that audit is MAQ's interpretation that an inspection of sample system's internal surfaces is sufficient to determine conditions that may affect nozzle performance. The auditor pointed out that in extreme cases, deposition on the external surface of a sampler and nozzle can bias air flow characteristics through the nozzle. While this level of deposition has not been noted at LANL, the intent of the regulation will be met and the external sampler surfaces will be inspected along with internal surfaces for the 2005 inspection cycle. Another audit recommendation was to generate a status report each calendar year, documenting the inspections and findings for each year. This will also be implemented for the 2005 inspection cycle. A presentation on the audit process will be given at the Rad-NESHAP special session of the July 2005 Health Physics Society meeting in Spokane.

A presentation on the "ripple effects" of the 2003 Subpart H changes have had on LANL operations was presented to the Aerosol Measurements User Group meeting in March 2005. This same talk will be given at the AMUG special session in Spokane during the July 2005 HPS meeting. 


\section{LANL Radionuclide Air Emissions Report}

\section{Section III. Dose Assessment}

\subsection{4(b) (7) Description of Dose Calculations}

Effective dose equivalent (or dose) calculations for point sources, unmonitored point sources, and nonpoint gaseous activation products from LANSCE and TA-18 were performed with the mainframe CAP88 version of AIRDOS. This procedure included using PREPAR to prepare the input file to AIRDOS and using the DARTAB preprocessor to prepare the dose conversion factor input file for DARTAB. The calculations used dose conversion factors taken from the RADRISK database that was distributed along with the CAP88 programs. ${ }^{7}$ Verification of the CAP88 code is performed regularly by running the EPA test cases originally distributed with the mainframe version. ${ }^{8}$

\section{Development of Source Term}

\section{Tritium emissions}

Tritium emissions from the Laboratory's tritium facilities are measured using a collection device known as a bubbler. This device enables the Laboratory to determine not only the total amount of tritium released but also whether it is in the elemental (HT) or oxide (HTO) form. The bubbler operates by pulling a continuous sample of air from the stack, which is then "bubbled" through three sequential vials containing ethylene glycol. The ethylene glycol collects the water vapor from the sample of air, including any tritium that is part of a water molecule (tritium oxide or HTO). After "bubbling" through these three vials, essentially all the HTO is removed from the air, leaving elemental tritium or HT. The sample, containing the elemental tritium, is then passed through a palladium catalyst that converts the elemental tritium to HTO. The sample is pulled through three additional vials containing ethylene glycol, which collects the newly formed HTO. The amount of HTO and HT is determined by analyzing the ethylene glycol for the presence of tritium using liquid scintillation counting (LSC). Although LANL's measurement device can distinguish the presence of HTO from HT, all emissions of tritium are assumed to be HTO for modeling the offsite dose. Because HTO contributes approximately 20,000 times more dose than an equivalent amount of HT, this is a conservative measure further ensuring that the dose to an off-site receptor is not underestimated.

Tritium emissions from LANSCE do not require monitoring under 40 CFR 61.93(b) (4) (i). The primary source for airborne tritium emissions at LANSCE is activation of water vapor in air and activation and subsequent evaporation of water in the cooling system of beam targets. Because of the low relative contribution of tritium to the off-site dose at LANSCE, formal monitoring for tritium was discontinued after July 2001. However, the tritium emissions for 2004 can be calculated based on the rate of generation measured in 2001. Using these rate-of-generation calculations, the tritium emissions from LANSCE stacks in 2004 were calculated to be about 3 Ci.

\section{Radioactive particle emissions}

Emissions of radioactive particulate matter, generated by operations at facilities such as the Chemistry and Metallurgy Research (CMR) Building and the Plutonium Facility (TA-55), are sampled using a glass-fiber filter. A continuous sample of stack air is pulled through the filter, where small particles of radioactive material are captured. These samples are analyzed weekly using gross alpha/beta counting and gamma spectroscopy to identify any 


\section{LANL Radionuclide Air Emissions Report}

increase in emissions and to identify short-lived radioactive materials. Every six months, LANL composites these stack samples for subsequent analysis at an off-site laboratory. These composite samples are analyzed to determine the total activity of materials such as ${ }^{234} \mathrm{U},{ }^{235} \mathrm{U},{ }^{238} \mathrm{U},{ }^{238} \mathrm{Pu},{ }^{239} \mathrm{Pu}$, and ${ }^{241} \mathrm{Am}$. These data are then combined with estimates of sampling losses and stack and sample flows to calculate emissions. For the case of radionuclides that have short-lived daughters, LANL includes these progeny in the source term. For example, the analytical laboratory measures the parent radionuclide ${ }^{238} \mathrm{U}$, and its short-lived progeny $\left({ }^{234} \mathrm{Th}\right.$ and $\left.{ }^{234 \mathrm{~m}} \mathrm{~Pa}\right)$ are assumed to be in equilibrium with ${ }^{238} \mathrm{U}$.

\section{Vapor form emissions}

Vapor emissions, generated by LANSCE operations and by hot-cell activities at CMR and TA-48, are sampled using a charcoal filter or canister. A continuous sample of stack air is pulled through a charcoal filter upon which vaporous emissions of radionuclides are adsorbed. The amount and identity of the radionuclide(s) present on the filter are determined through the use of gamma spectroscopy. This information is then used to calculate emissions. Examples of radionuclides of this type include ${ }^{68} \mathrm{Ge}$ and ${ }^{76} \mathrm{Br}$.

\section{Gaseous mixed activation products (GMAP)}

GMAP emissions resulting from activities at LANSCE are measured using near real-time monitoring data. A sample of stack air is pulled through an ionization chamber that measures the total amount of radioactivity in the sample. Specific radioisotopes are identified through the use of gamma spectroscopy and decay curves. This information is then used to calculate emissions. Radionuclides of this type include ${ }^{11} \mathrm{C},{ }^{13} \mathrm{~N}$, and ${ }^{15} \mathrm{O}$.

\section{Summary of Input Parameters}

Effective dose equivalents to potential receptors were calculated for all radioactive air emissions from sampled LANL point sources. Input parameters for these point sources are provided in Table 3 . The geographic locations of the release points, given in New Mexico State Plane coordinates, are provided in Table 4. The relationships of receptor locations to the individual release points are provided in Table 5. The nearest receptor location is different for each point source. However, because the majority of the yearly dose has historically been caused by LANSCE emissions, the LANSCE critical receptor location has historically been the maximum dose location for all Laboratory emissions. This location is a business office approximately $800 \mathrm{~m}$ north-northeast of the LANSCE stacks. Emissions and doses from LANSCE are calculated on a monthly basis during beam operations to ensure continued compliance with the $10 \mathrm{mrem} / \mathrm{yr}$ standard.

Other site-specific parameters and the sources of these data are provided in Table 6. The LANL Meteorology and Air Quality Group (MAQ) operates an on-site network of meteorological monitoring towers. Data gathered by the towers are summarized and formatted for input to the CAP88 program. For 2004, data from two different towers were used for the air-dispersion modeling; the tower data that is most representative of the release point is applied. Copies of the meteorological data files used for the 2004 dose assessment are provided in Table 7. 


\section{LANL Radionuclide Air Emissions Report}

The MAQ Group also inputs population array data to the CAP88 program. The data file represents a 16-sector polartype array, with 20 radial distances for each sector. Population arrays are developed for each release point using U.S. Census data, updated with annual projections from the New Mexico Bureau of Business and Economic Research. An example of the population array used for the LANSCE facility is provided in Table 8. For agricultural array input, LANL is currently using the default values in CAP88. Finally, the radionuclide inputs for the point sources monitored in 2004 are provided in Table 9.

\section{Public Receptors}

Compliance with the annual dose standard is determined by calculating the highest EDE to any member of the public at any off-site point where there is a residence, school, business, or office. Late in the calendar year, a visual tour of the laboratory vicinity was completed to identify new locations inhabited by the public; that is, new off-site public receptors that had not existed in the year previous to this assessment. Some new businesses and residences were noted in the 2004 tour. In this report, the nearest off-site point is defined to be the area of public inhabitation where the highest off-site dose occurs for a given emissions source. For the 2004 compliance assessment, LANLwide doses were evaluated at the nearest off-site point for each monitored emissions stack, as well as a number of additional key locations.

Starting in CY 2001, LANL began leasing some office buildings and property to parties not directly employed by LANL. One such example is the ICON facility located at TA-46. Another case is the establishment of office and workspace for U.S. Forest Service personnel to be housed on-site during periods of increased danger from wildfires. In neither case are these personnel determined to be public receptors. Personnel of this type are considered to be subcontractors to DOE, similar to security guards and maintenance workers. These workers must carry a LANL identification badge and pass through a gate controlled for access by LANL/DOE employees and contractors only. This determination is in compliance with the EPA guidance on leased DOE facilities. ${ }^{9}$

\section{Point Source Emissions Modeling}

The CAP88 program was used to calculate doses from both the monitored and unmonitored point sources at LANL. The CAP88 program uses on-site meteorological data to calculate atmospheric dispersion and transport of the radioactive effluents. There are a number of radionuclides monitored in LANL effluents that are not included in the dose factor database used by CAP88. ${ }^{8}$ For these radionuclides, such as ${ }^{76} \mathrm{Br},{ }^{68} \mathrm{Ge},{ }^{10} \mathrm{C},{ }^{14} \mathrm{O}$ and ${ }^{16} \mathrm{~N}$, etc., LANL uses the CAP88 code to calculate airborne concentrations. We then apply exposure-to-dose conversion factors from EPA approved sources, such as dose conversion factors from U.S. DOE reports ${ }^{10,11}$ or EPA's Federal Guidance Reports. ${ }^{12,13}$ At the LANL-wide maximum dose location for 2004, the total estimated dose arising from emissions of radionuclides not included in the CAP88 library was about $0.001 \mathrm{mrem}$. This number is included in the total annual dose. The LANL MAQ Group has informed the regional office of the U.S. EPA of the various steps and methods used to calculate the doses from such radionuclides. ${ }^{14}$ 


\section{LANL Radionuclide Air Emissions Report}

\section{LANSCE Fugitive Emission Modeling}

Some of the GMAP created at the accelerator target cells migrate into room air and into the environment. These fugitive sources are continuously monitored throughout the beam-operating period. In 2004, approximately $80 \mathrm{Ci}$ of

${ }^{11} \mathrm{C}$ and $3 \mathrm{Ci}$ of ${ }^{41} \mathrm{Ar}$ were released from LANSCE as fugitive emissions. This source was modeled as an area source using CAP88 and meteorological data coinciding with the LANSCE run cycle. Fugitive effluents were modeled from three areas at LANSCE; additional source information is provided in Table 10.

\section{TA-18 Nonpoint Emission Modeling}

This site consists of a variety of nuclear assemblies that are operated at near-critical conditions. During the nearcritical operations, neutrons are generated that, in turn, activate argon atoms in the air surrounding the assembly. Operations conducted in 2004 were evaluated for their potential to create ${ }^{41} \mathrm{Ar}$ gas. In 2004, approximately $0.9 \mathrm{Ci}$ of

${ }^{41} \mathrm{Ar}$ was generated, and the dose was evaluated with CAP88. Additional source information is provided in Table 10.

\section{Environmental Data}

The net annual average ambient concentration of airborne radionuclides measured at 18 air sampling stations (Figure 4) is calculated by subtracting an appropriate background concentration value. The net concentration at each air sampler is converted to the annual EDE using Table 2 of Appendix E of 40 CFR 61 and applying the valid assumption that each table value is equivalent to $10 \mathrm{mrem} / \mathrm{yr}$ from all appropriate exposure pathways (100\% occupancy assumed at the respective location). ${ }^{15}$ Dose assessment results from each air sampler are given in Table 11. The operational performance and analytical completeness of each air sampler is provided in Table 12.

\section{LANSCE Monthly Assessments}

The MAQ group evaluates the dose from short-lived radioactive gases released from LANSCE on a monthly basis. The monthly dose values are evaluated with the actual meteorology for the month and these doses are shown in Table 13. For 2004 the MAQ group also evaluated the total LANSCE emissions for the year with run-cycle meteorology and compared the results to the monthly values summed for the calendar year; the values for these two assessments were 1.52 and 1.47 mrem, respectively. The values would not be expected to match, but should show satisfactory agreement between each other. We used the values from the monthly sum (that is, $1.47 \mathrm{mrem}$ ) in the calculation of the total dose, since it is a more accurate estimation of the dose from GMAP emissions.

\section{Highest EDE Determination}

A major change to the procedure for determining the highest EDE was necessary for CY 1999 because of significantly reduced emissions from the LANSCE facility. Over the previous nine years to 1999, the off-site EDE from LANSCE operations averaged about 5 mrem. For 1999, the highest off-site EDE from the LANSCE facility was about $0.01 \mathrm{mrem}$. The highest off-site EDE location for LANSCE effluents is a business in the East Gate area (2470 East Gate Drive). Because the contribution from LANSCE for 1999 was greatly reduced, the location of the highest off-site dose was not as readily established as had been in the past. 


\section{LANL Radionuclide Air Emissions Report}

In late 1999, LANL began working on a plan to ensure that the location of the highest public dose could be determined. This plan uses a multi-step approach, and the steps used were presented to the local Citizen's Advisory Board (CAB) for LANL for their review and comment. This approach was approved by the CAB for CY 1999 and has since been used in all subsequent dose assessments. Table 14 shows the sites identified by LANL for the purposes of finding the location of the highest off-site dose. Also shown in the table is the AIRNET sampling station that the MAQ group associated with the selected public receptor location. The LANL-wide doses at these various off-site locations are provided in Table 14. The highest off-site dose location was determined to be the East Gate area because of increased emissions from LANSCE in 2004 as compared to the 1999 emissions. 


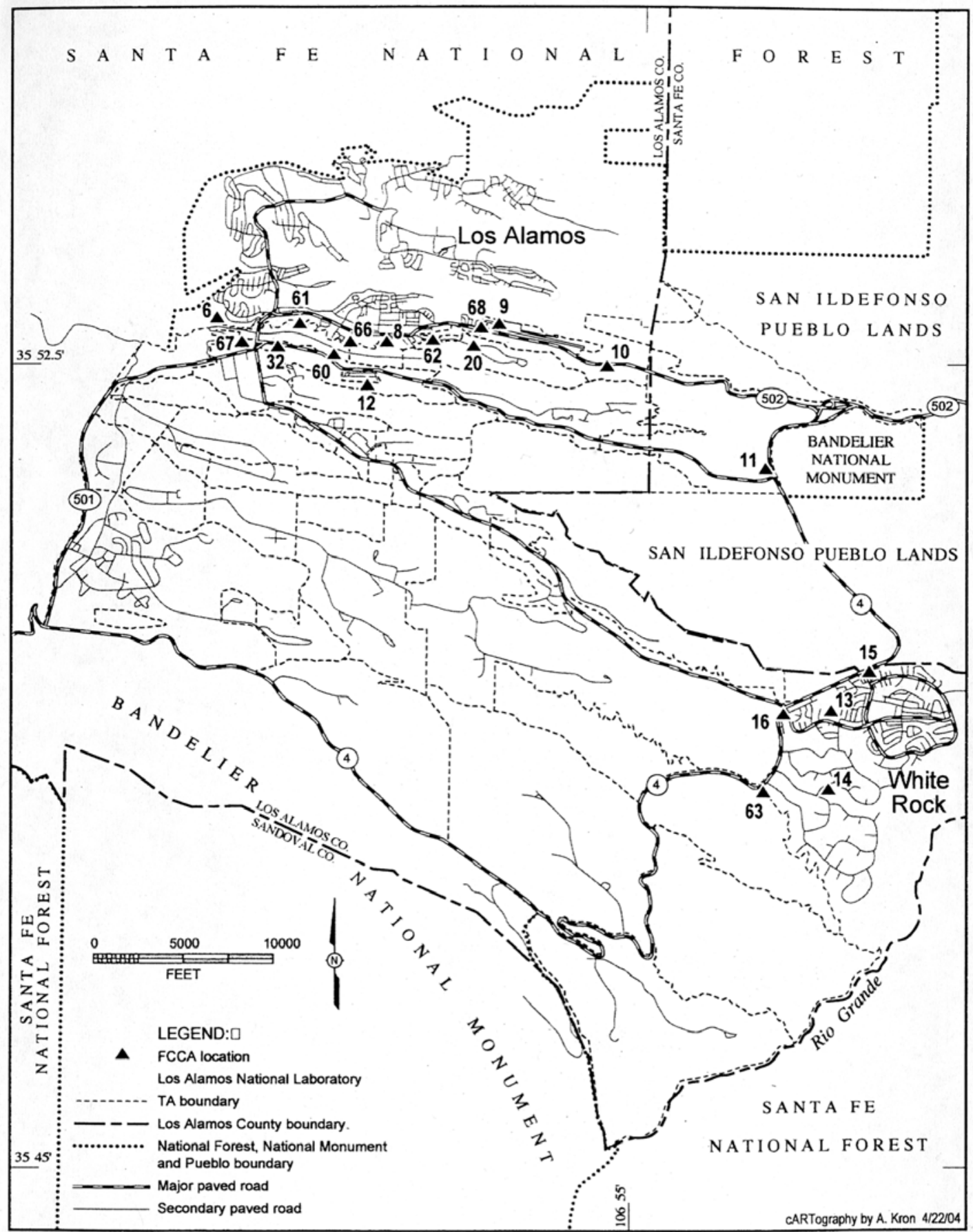

Figure 4. Locations of air sampling stations used for nonpoint source compliance. 


\section{LANL Radionuclide Air Emissions Report}

\subsection{Compliance Assessment}

The highest effective dose equivalent (EDE) to any member of the public at any off-site point where there is a residence, school, or business office was 1.68 mrem for radionuclides released by LANL in 2004. This dose was calculated by adding up the doses for each of the point sources at LANL, the diffuse and fugitive gaseous activation products from LANSCE and TA-18, and the dose measured by the ambient air sampler in the vicinity of the public receptor location. The compliance assessment also includes a potential dose contribution of about $0.1 \mathrm{mrem}$ from unmonitored stacks. Because the emissions estimates do not account for pollution control systems, the actual dose will be significantly less for the unmonitored point sources. Also, this dose includes a minor contribution from radionuclides not included in CAP88. Table 15 of this report provides the compliance assessment summary. The location of the off-site point of highest EDE for 2004 was a business office at 2470 East Gate Drive; this location is the same as the location of the previous year's assessment.

\section{Section IV. Constructions and Modifications}

\subsection{4(b) (8) Constructions and Modifications}

A brief description of constructions and modifications that were completed and/or reviewed in 2004 but for which the requirement to apply for approval to construct or modify was waived under 61.96 is normally provided here. The MAQ Group for LANL/DOE maintains the documents developed to support the waiver. We are providing additional information on other Rad-NESHAP activities noteworthy for 2004.

\section{Ultra-Cold Neutron Target and Moderator System}

In April 2004, research on very low energy (“ultra-cold") neutrons took place in Technical Area 53's Experimental Area B. A low-current ion beam was delivered to a tungsten target and helium moderator/beamstop assembly. The experiments are expected to continue into calendar year (CY) 2005. As a by-product of these experiments, proton and fast neutron interactions with helium resulted in low-level production of tritium. For this project, the uncontrolled dose was conservatively estimated to be $2.6 \mathrm{E}-10 \mathrm{mrem} / \mathrm{yr}$. The maximum uncontrolled dose from annual activities could increase to approximately 7.7E-10 mrem/yr in future years. The tritium production was modeled with CAP88 to determine these off-site dose rates.

\section{(61.96) Activity Relocations}

There were no activity relocations and there were no first-time uses of radionuclides in existing buildings identified in CY 2004. 


\section{LANL Radionuclide Air Emissions Report}

\section{Section V. Additional Information}

This section is provided pursuant to DOE guidance and is not required by Subpart-H reporting requirements.

\section{Unplanned Releases}

During 2004, the Laboratory had no instances of increased airborne emissions of radioactive materials that required reporting to the EPA. There were no instances of an unplanned event.

\section{Environmental Monitoring}

The MAQ Group operates an extensive environmental monitoring network that includes several environmental monitoring stations located near the LANSCE boundary inhabited by the public. Measurement systems at these stations include thermoluminescent dosimeters, continuously operated air samplers, and in situ high-pressure ion chambers. The combination of these measurement systems allows for monitoring of radionuclide air concentrations and the radiation exposure rate. Results for air sampling are published here; results for all monitoring data are published in the Annual Site Environmental Surveillance Report for DOE order compliance.

\section{Other Supplemental Information}

- 80-km collective effective (population) dose equivalent for 2004 airborne releases: 0.9 person-rem.

- Compliance with Subparts Q and T of 40 CFR 61—Radon-222 Emissions.

- These regulations apply to ${ }^{222} \mathrm{Rn}$ emissions from DOE storage/disposal facilities that contain byproduct material. "Byproduct material" is the tailings or wastes produced by the extraction or concentration of uranium from ore. Although this regulation targets uranium mills, LANL has likely stored small amounts of byproduct material used in experiments in the TA-54 low-level waste facility, Area G; this practice makes the Laboratory subject to this regulation. Subject facilities cannot exceed an emissions rate of $20 \mathrm{pCi} / \mathrm{m}^{2} \mathrm{~s}$ of ${ }^{222} \mathrm{Rn}$. In 1993 and 1994, LANL conducted a study to characterize emissions from the Area G disposal site ${ }^{16}$. This study showed an average emission rate of $0.14 \mathrm{pCi} / \mathrm{m}^{2} \mathrm{~s}$ for Area $\mathrm{G}$. The performance assessment for Area $\mathrm{G}$ has determined that there will not be a significant increase in ${ }^{222} \mathrm{Rn}$ emissions in the future. ${ }^{17}$

- Potential to exceed 0.1 mrem from LANL sources of ${ }^{222} \mathrm{Rn}$ or ${ }^{220} \mathrm{Rn}$ emissions: not applicable at LANL.

- Status of compliance with EPA effluent monitoring requirements: as of June 3, 1996, LANL came into compliance with EPA effluent monitoring requirements. 
Table 1. 40-61.94(b)(4-5) Release Point Data

\begin{tabular}{|c|c|c|c|c|c|}
\hline ESIDNUM & Location & $\begin{array}{c}\text { Control } \\
\text { Description }\end{array}$ & $\begin{array}{c}\text { Number of } \\
\text { Effluent Controls }\end{array}$ & $\begin{array}{l}\text { Control } \\
\text { Efficiency }\end{array}$ & Monitored \\
\hline 03001600 & TA-03-16 & none & 0 & $0 \%$ & $\square$ \\
\hline 03002913 & TA-03-29-1 & unknown & 0 & $0 \%$ & $\square$ \\
\hline 03002914 & TA-03-29-2 & HEPA & 2 & $99.95 \%$ each & $\checkmark$ \\
\hline 03002915 & TA-03-29-2 & HEPA & 2 & $99.95 \%$ each & $\checkmark$ \\
\hline 03002919 & TA-03-29-3 & Aerosol 95 & 1 & $80 \%$ & $\nabla$ \\
\hline 03002920 & TA-03-29-3 & Aerosol 95 & 1 & $80 \%$ & $\nabla$ \\
\hline 03002923 & TA-03-29-4 & FARR $30 / 30$ & 1 & $\sim 20 \%$ & $\nabla$ \\
\hline 03002924 & TA-03-29-4 & FARR 30/30 & 1 & $\sim 20 \%$ & $\checkmark$ \\
\hline 03002928 & TA-03-29-5 & HEPA & 2 & $99.95 \%$ each & $\nabla$ \\
\hline 03002929 & TA-03-29-5 & HEPA & 2 & $99.95 \%$ each & $\nabla$ \\
\hline 03002932 & TA-03-29-7 & HEPA & 2 & $99.95 \%$ each & $\nabla$ \\
\hline 03002933 & TA-03-29-7 & HEPA & 2 & $99.95 \%$ each & $\checkmark$ \\
\hline 03002937 & TA-03-29-V & HEPA & 2 & $99.95 \%$ each & $\nabla$ \\
\hline 03002944 & TA-03-29-9 & RIGA-Flow 220 & 1 & $80 \%$ & $\nabla$ \\
\hline 03002945 & TA-03-29-9 & RIGA-Flow 220 & 1 & $80 \%$ & $\checkmark$ \\
\hline 03002946 & TA-03-29-9 & RIGA-Flow 220 & 1 & $80 \%$ & $\checkmark$ \\
\hline 03003299 & TA-03-32 & unknown & 0 & $0 \%$ & $\square$ \\
\hline 03003400 & TA-03-34 & none & 0 & $0 \%$ & $\square$ \\
\hline 03003501 & TA-03-35 & HEPA & 1 & $99.95 \%$ & $\square$ \\
\hline 03003599 & TA-03-35 & unknown & 0 & $0 \%$ & $\square$ \\
\hline 03003999 & TA-03-39 & none & 0 & $0 \%$ & $\square$ \\
\hline 03004025 & TA- $03-40$ & HEPA & 1 & $99.95 \%$ & $\square$ \\
\hline 03006601 & TA-03-66 & none & 0 & $0 \%$ & $\square$ \\
\hline 03006602 & TA-03-66 & none & 0 & $0 \%$ & $\square$ \\
\hline 03006603 & TA-03-66 & none & 0 & $0 \%$ & $\square$ \\
\hline 03006604 & TA-03-66 & none & 0 & $0 \%$ & $\square$ \\
\hline 03006605 & TA-03-66 & none & 0 & $0 \%$ & $\square$ \\
\hline 03006606 & TA-03-66 & none & 0 & $0 \%$ & $\square$ \\
\hline 03006626 & TA-03-66 & HEPA & 1 & $99.95 \%$ & $\square$ \\
\hline
\end{tabular}


Table 1 (Continued)

\begin{tabular}{|c|c|c|c|c|c|}
\hline ESIDNUM & Location & $\begin{array}{c}\text { Control } \\
\text { Description }\end{array}$ & $\begin{array}{c}\text { Number of } \\
\text { Effluent Controls }\end{array}$ & $\begin{array}{c}\text { Control } \\
\text { Efficiency }\end{array}$ & Monitored \\
\hline 03006654 & TA-3-66 & HEPA & 1 & $99.95 \%$ & $\square$ \\
\hline 03006699 & TA-03-66 & none & 0 & $0 \%$ & $\square$ \\
\hline 03010222 & TA-03-102 & HEPA & 1 & $99.95 \%$ & $\nabla$ \\
\hline 03010225 & TA-03-102 & HEPA & 1 & $99.95 \%$ & $\square$ \\
\hline 03169800 & TA-03-1698 & none & 0 & $0 \%$ & $\square$ \\
\hline 09002103 & TA-09-21 & none & 0 & $0 \%$ & $\square$ \\
\hline 16020299 & TA-16-202 & unknown & 0 & $0 \%$ & $\square$ \\
\hline 16020504 & TA-16-205 & $\mathrm{CR} / \mathrm{MS}$ & 1 & $>99 \%$ & $\nabla$ \\
\hline 16020599 & TA-16-205 & none & 0 & $0 \%$ & $\square$ \\
\hline 18016899 & TA-18-168 & none & 0 & $0 \%$ & $\square$ \\
\hline 21000507 & TA-21-5 & HEPA & 2 & $99.95 \%$ each & $\square$ \\
\hline 21015001 & TA-21-150 & HEPA & 1 & $99.95 \%$ & $\square$ \\
\hline 21015505 & TA-21-155 & $\mathrm{CR} / \mathrm{MS}$ & 1 & $>99 \%$ & $\nabla$ \\
\hline 21020901 & TA-21-209 & $\mathrm{CR} / \mathrm{MS}$ & 1 & $>99 \%$ & $\nabla$ \\
\hline 21020999 & TA-21-209 & none & 0 & $0 \%$ & $\square$ \\
\hline 21025704 & TA-21-257 & none & 0 & $0 \%$ & $\square$ \\
\hline 35000200 & TA-35-2 & none & 0 & $0 \%$ & $\square$ \\
\hline 35021305 & TA-35-213 & none & 0 & $0 \%$ & $\square$ \\
\hline 36000104 & TA-36-1 & unknown & 0 & $0 \%$ & $\square$ \\
\hline 41000104 & TA-41-1 & HEPA & 2 & $99.95 \%$ each & $\square$ \\
\hline 41000417 & TA-41-4 & none & 0 & $0 \%$ & $\square$ \\
\hline 43000100 & TA-43-1 & none & 0 & $0 \%$ & $\square$ \\
\hline 46002499 & TA-46-24 & none & 0 & $0 \%$ & $\square$ \\
\hline 46003100 & TA-46-31 & none & 0 & $0 \%$ & $\square$ \\
\hline 46004106 & TA-46-41 & none & 0 & $0 \%$ & $\square$ \\
\hline 46015405 & TA-46-154 & none & 0 & $0 \%$ & $\square$ \\
\hline 46015899 & TA-46-158 & none & 0 & $0 \%$ & $\square$ \\
\hline 46020099 & TA-46-200 & none & 0 & $0 \%$ & $\square$ \\
\hline 48000107 & TA-48-1 & HEPA/Charcoal Bed & 2 & $99.95 \%$ each & $\nabla$ \\
\hline 48000111 & TA-48-1 & none & 0 & $0 \%$ & $\square$ \\
\hline 48000115 & TA-48-1 & none & 0 & $0 \%$ & $\square$ \\
\hline
\end{tabular}


Table 1 (Continued)

\begin{tabular}{|c|c|c|c|c|c|}
\hline ESIDNUM & Location & $\begin{array}{c}\begin{array}{c}\text { Control } \\
\text { Description }\end{array} \\
\end{array}$ & $\begin{array}{c}\begin{array}{c}\text { Number of } \\
\text { Effluent Controls }\end{array} \\
\end{array}$ & $\begin{array}{c}\text { Control } \\
\text { Efficiency }\end{array}$ & Monitored \\
\hline 48000135 & TA-48-1 & none & 0 & $0 \%$ & $\square$ \\
\hline 48000145 & TA-48-1 & none & 0 & $0 \%$ & $\square$ \\
\hline 48000154 & TA-48-1 & HEPA & 2 & $99.95 \%$ each & $\nabla$ \\
\hline 48000160 & TA-48-1 & HEPA & 1 & $99.95 \%$ & $\nabla$ \\
\hline 48000166 & TA-48-1 & HEPA & 2 & $99.95 \%$ each & $\square$ \\
\hline 48000167 & TA-48-1 & HEPA & 2 & $99.95 \%$ each & $\square$ \\
\hline 48004500 & TA-48-45 & none & 0 & $0 \%$ & $\square$ \\
\hline 50000102 & TA-50-1 & HEPA & 1 & $99.95 \%$ each & $\nabla$ \\
\hline 50000299 & TA-50-2 & none & 0 & $0 \%$ & $\square$ \\
\hline 50003701 & TA-50-37 & HEPA & 2 & $99.95 \%$ each & $\checkmark$ \\
\hline 50006901 & TA-50-69 & HEPA & 1 & $99.95 \%$ & $\square$ \\
\hline 50006902 & TA-50-69 & HEPA & 1 & $99.95 \%$ & $\square$ \\
\hline 50006903 & TA-50-69 & HEPA & 2 & $99.95 \%$ each & $\nabla$ \\
\hline 53000116 & TA-53-1 & unknown & 0 & $0 \%$ & $\square$ \\
\hline 53000303 & TA-53-3 & HEPA & 1 & $99.95 \%$ & $\nabla$ \\
\hline 53000702 & TA-53-7 & HEPA & 1 & $99.95 \%$ & $\nabla$ \\
\hline 53000799 & TA-53-7 & none & 0 & $0 \%$ & $\square$ \\
\hline 53109099 & TA-53-1090 & none & 0 & $0 \%$ & $\square$ \\
\hline 54003399 & TA-54-33 & HEPA & 1 & $99.95 \%$ & $\square$ \\
\hline 54003699 & TA-54-36 & HEPA & 1 & $99.95 \%$ & $\square$ \\
\hline 54004999 & TA-54-49 & unknown & 0 & $0 \%$ & $\square$ \\
\hline 54021599 & TA-54-215 & unknown & 0 & $0 \%$ & $\square$ \\
\hline 54022499 & TA-54-224 & unknown & 0 & $0 \%$ & $\square$ \\
\hline 54028101 & TA-54-281 & HEPA & 1 & $99.95 \%$ & $\square$ \\
\hline 54041201 & TA-54-412 & HEPA & 1 & 99.95 & $\square$ \\
\hline 54100199 & TA-54-1001 & none & 0 & $0 \%$ & $\square$ \\
\hline 54100999 & TA-54-1009 & none & 0 & $0 \%$ & $\square$ \\
\hline 55000415 & TA-55-4 & HEPA & 4 & $99.95 \%$ each & $\nabla$ \\
\hline 55000416 & TA-55-4 & HEPA & 4 & $99.95 \%$ each & $\nabla$ \\
\hline 59000100 & TA-59-1 & none & 0 & $0 \%$ & $\square$ \\
\hline
\end{tabular}


2004 LANL Radionuclide Air Emissions Report

Table 2. 40-61.94(b)(6) Distances from Monitored Release Points to Nearest Receptor

\begin{tabular}{lcc} 
ESIDNUM & Nearest Receptor $(\mathbf{m})$ & Receptor Direction \\
\hline 03002914 & 731 & NE \\
03002915 & 732 & NE \\
03002919 & 836 & NNE \\
03002920 & 835 & NNE \\
03002923 & 575 & NNW \\
03002924 & 575 & NNW \\
03002928 & 936 & NE \\
03002929 & 937 & NE \\
03002932 & 856 & NNE \\
03002933 & 855 & NNE \\
03002937 & 870 & NE \\
03002944 & 937 & NNE \\
03002945 & 939 & NNE \\
03002946 & 938 & NNE \\
03010222 & 746 & N \\
16020504 & 778 & SSW \\
21015505 & 680 & NNW \\
21020901 & 712 & NNW \\
48000107 & 749 & NNE \\
48000154 & 751 & NNE \\
48000160 & 764 & NNE \\
50000102 & 1183 & N \\
50003701 & 1171 & N \\
50006903 & 1186 & N \\
53000303 & 800 & NNE \\
53000702 & 944 & NNE \\
55000415 & 1016 & NNE \\
55000416 & 1089 & \\
& & \\
\hline & & \\
\hline
\end{tabular}


Table 3. 40-61.94(b)(7) User-Supplied Data-

Monitored Stack Parameters

\begin{tabular}{|c|c|c|c|c|}
\hline ESIDNUM & Height (m) & Diameter (m) & Exit Velocity (m/s) & $\begin{array}{c}\text { Nearest } \\
\text { Meteorological } \\
\text { Tower } \\
\end{array}$ \\
\hline 03002914 & 15.9 & 1.07 & 7.66 & TA- 6 \\
\hline 03002915 & 15.9 & 1.05 & 23.22 & TA- 6 \\
\hline 03002919 & 15.9 & 1.07 & 21.50 & TA- 6 \\
\hline 03002920 & 15.9 & 1.07 & 17.95 & TA- 6 \\
\hline 03002923 & 15.9 & 1.07 & 23.74 & TA- 6 \\
\hline 03002924 & 15.9 & 1.06 & 15.54 & TA-6 \\
\hline 03002928 & 15.9 & 1.05 & 20.02 & TA- 6 \\
\hline 03002929 & 15.9 & 1.07 & 25.58 & TA- 6 \\
\hline 03002932 & 15.9 & 1.07 & 15.75 & TA-6 \\
\hline 03002933 & 15.9 & 1.06 & 26.14 & TA-6 \\
\hline 03002937 & 16.8 & 0.20 & 12.51 & TA- 6 \\
\hline 03002944 & 16.5 & 1.52 & 8.44 & TA- 6 \\
\hline 03002945 & 16.5 & 1.52 & 9.32 & TA- 6 \\
\hline 03002946 & 16.5 & 1.88 & 5.52 & TA-6 \\
\hline 03010222 & 13.4 & 0.91 & 0.44 & TA- 6 \\
\hline 16020504 & 18.3 & 0.46 & 19.98 & TA-6 \\
\hline 21015505 & 29.9 & 0.79 & 9.85 & TA-53 \\
\hline 21020901 & 22.9 & 1.22 & 11.51 & TA-53 \\
\hline 48000107 & 13.4 & 0.30 & 20.64 & TA-6 \\
\hline 48000154 & 13.1 & 0.91 & 5.99 & TA- 6 \\
\hline 48000160 & 12.4 & 0.38 & 7.18 & TA- 6 \\
\hline 50000102 & 15.5 & 1.82 & 11.96 & TA-6 \\
\hline 50003701 & 12.4 & 0.91 & 5.60 & TA- 6 \\
\hline 50006903 & 10.5 & 0.31 & 7.09 & TA-6 \\
\hline 53000303 & 33.5 & 0.91 & 11.41 & TA-53 \\
\hline 53000702 & 13.1 & 0.91 & 8.99 & TA-53 \\
\hline 55000415 & 9.5 & 0.93 & 6.94 & TA- 6 \\
\hline 55000416 & 9.5 & 0.94 & 11.72 & TA- 6 \\
\hline
\end{tabular}


Table 4. 61.94(b)(7) User-Supplied Data --- Monitored Stack Parameters --- NM State Plane Coordinates (NAD '83)

\begin{tabular}{|c|c|c|}
\hline ESIDNUM & Easting & Northing \\
\hline 03002914 & $1,619,176$ & $1,772,806$ \\
\hline 03002915 & $1,619,171$ & $1,772,805$ \\
\hline 03002919 & $1,619,252$ & $1,772,350$ \\
\hline 03002920 & $1,619,257$ & $1,772,352$ \\
\hline 03002923 & $1,618,691$ & $1,772,719$ \\
\hline 03002924 & $1,618,686$ & $1,772,718$ \\
\hline 03002928 & $1,618,774$ & $1,772,265$ \\
\hline 03002929 & $1,618,767$ & $1,772,265$ \\
\hline 03002932 & $1,619,268$ & $1,772,267$ \\
\hline 03002933 & $1,619,272$ & $1,772,269$ \\
\hline 03002937 & $1,618,966$ & $1,772,397$ \\
\hline 03002944 & $1,618,987$ & $1,772,121$ \\
\hline 03002945 & $1,618,977$ & $1,772,120$ \\
\hline 03002946 & $1,618,982$ & $1,772,121$ \\
\hline 03010222 & $1,618,354$ & $1,772,074$ \\
\hline 16020504 & $1,609,447$ & $1,760,866$ \\
\hline 21015505 & $1,633,757$ & $1,774,182$ \\
\hline 21020901 & $1,633,991$ & $1,774,175$ \\
\hline 48000107 & $1,623,591$ & $1,770,693$ \\
\hline 48000154 & $1,623,744$ & $1,770,650$ \\
\hline 48000160 & $1,623,613$ & $1,770,638$ \\
\hline 50000102 & $1,626,157$ & $1,769,086$ \\
\hline 50003701 & $1,625,757$ & $1,769,109$ \\
\hline 50006903 & $1,625,579$ & $1,769,065$ \\
\hline 53000303 & $1,638,133$ & $1,771,546$ \\
\hline 53000702 & $1,638,057$ & $1,771,054$ \\
\hline 55000415 & $1,624,870$ & $1,769,742$ \\
\hline 55000416 & $1,624,675$ & $1,769,550$ \\
\hline
\end{tabular}


Table 4. 61.94(b)(7) User-Supplied Data --- Monitored Stack Parameters -- NM State Plane Coordinates (NAD '83)

This page has been removed for operational security purposes. Please contact ENVMAQ at (505) 665-8855 for a hard copy of the NM State Plane coordinates for monitored stacks.

Table 5. 40-61.94(b)(7) User-Supplied Data --- Highest Off-Site Dose Location for Monitored Release Points

\begin{tabular}{|c|c|c|c|}
\hline ESHIDNUM & $\begin{array}{c}\text { Associated Meteorological } \\
\text { Tower } \\
\end{array}$ & $\begin{array}{l}\text { Distance to LANL Highest } \\
\text { Dose Location }(\mathrm{m})\end{array}$ & $\begin{array}{c}\text { Direction to LANL Highes } \\
\text { Dose Location } \\
\end{array}$ \\
\hline 03002914 & TA-06 & 5,981 & E \\
\hline 03002915 & TA-06 & 5,983 & E \\
\hline 03002919 & TA-06 & 5,969 & E \\
\hline 03002920 & TA-06 & 5,967 & E \\
\hline 03002923 & TA-06 & 6,130 & $\mathrm{E}$ \\
\hline 03002924 & TA-06 & 6,132 & E \\
\hline 03002928 & TA-06 & 6,116 & E \\
\hline 03002929 & TA-06 & 6,118 & E \\
\hline 03002932 & TA-06 & 5,966 & E \\
\hline 03002933 & TA-06 & 5,965 & E \\
\hline 03002937 & TA-06 & 6,054 & $\mathrm{E}$ \\
\hline 03002944 & TA-06 & 6,055 & E \\
\hline 03002945 & TA-06 & 6,057 & E \\
\hline 03002946 & TA-06 & 6,057 & E \\
\hline 03010222 & TA-06 & 6,249 & $\mathrm{E}$ \\
\hline 16020504 & TA-06 & 9,799 & ENE \\
\hline 21015505 & TA-53 & 1,525 & E \\
\hline 21020901 & TA-53 & 1,453 & E \\
\hline 48000107 & TA-06 & 4,730 & ENE \\
\hline 48000154 & TA-06 & 4,714 & ENE \\
\hline 48000160 & TA-06 & 4,733 & ENE \\
\hline 50000102 & TA-06 & 4,131 & ENE \\
\hline 50003701 & TA-06 & 4,242 & ENE \\
\hline 50006903 & TA-06 & 4,297 & ENE \\
\hline 53000303 & TA-53 & 800 & NNE \\
\hline 53000702 & TA-53 & 944 & NNE \\
\hline 55000415 & TA-53 & 4,434 & ENE \\
\hline 55000416 & TA-53 & 4,508 & ENE \\
\hline
\end{tabular}




\section{Table 6. 40-61.94(b)(7) User-Supplied Data- Other Input Parameters}

$\begin{array}{lrcccl}\text { Description } & \text { Value } & \text { Units } & \text { CAP88 Variable Name } & \text { Reference } \\ & & & & & \\ \text { Annual rainfall rate } & 45.3 & \mathrm{~cm} / \mathrm{y} & \text { RR } & \text { Bowen (1990) } \\ \text { Lid height } & 1525 & \mathrm{~m} & \text { LIPO } & \text { Holzworth (1972) } \\ \text { Annual median temp } & 281.9 & \mathrm{~K} & \mathrm{TA} & \text { Bowen (1990) } \\ \text { E-vertical temperature gradient } & 0.02 & \mathrm{~K} / \mathrm{m} & \text { TG } & \text { EPA (1995) } \\ \text { F-vertical temperature gradient } & 0.035 & \mathrm{~K} / \mathrm{m} & \text { TG } & \text { EPA (1995) } \\ \text { G-vertical temperature gradient } & 0.035 & \mathrm{~K} / \mathrm{m} & \text { TG } & \text { EPA (1995) } \\ \text { Food supply fraction - local vegetables } & 0.076 & & \text { F1V } & \text { EPA (1989) } \\ \text { Food supply fraction - vegetable regional } & 0.924 & & \text { F2V } & \text { EPA (1989) } \\ \text { Food supply fraction - vegetable imported } & 0 & & \text { F3V } & \text { EPA (1989) } \\ \text { Food supply fraction - meat local } & 0.008 & & \text { F1B } & \text { EPA (1989) } \\ \text { Food supply fraction - meat regional } & 0.992 & & \text { F2B } & \text { EPA (1989) } \\ \text { Food supply fraction - meat imported } & 0 & & \text { F3B } & \text { EPA (1989) } \\ \text { Food supply fraction - milk local } & 0 & \text { F1M } & \text { EPA (1989) } \\ \text { Food supply fraction - milk regional } & 1 & \text { F2M } & \text { EPA (1989) } \\ \text { Food supply fraction - milk imported } & 0 & \text { F3M } & \text { EPA (1989) } \\ \text { Ground surface roughness factor } & 0.5 & \text { GSCFAC } & \text { EPA (1989) }\end{array}$

Brent M. Bowen, "Los Alamos Climatology,” Los Alamos National Laboratory report LA-11735-MS (1990).

George C. Holzworth, "Mixing Heights, Wind Speeds, and Potential for Urban Air Pollution throughout the Contiguous United States," U.S. Environmental Protection Agency Office of Air Programs report (1972).

U.S. Environmental Protection Agency, "User's Guide for the Industrial Source Complex (ISC3) Dispersion Models Volume II - Description of Model Algorithms,” EPA-454/B-95-003b (1995).

U.S. Environmental Protection Agency, "Risk Assessments Methodology, Environmental Impact Statement, NESHAPS for Radionuclides, Background Information Document - Volume 1,” EPA/520/189-005 (1989). 
2004 LANL Radionuclide Air Emissions Report

\author{
Table 7. 40-61.94(b)(7) User-Supplied Data- \\ Wind Frequency Arrays
}

CAP88 Input Data For 2004 TA-6 Meteorological Tower (99.5\% Data Completeness)

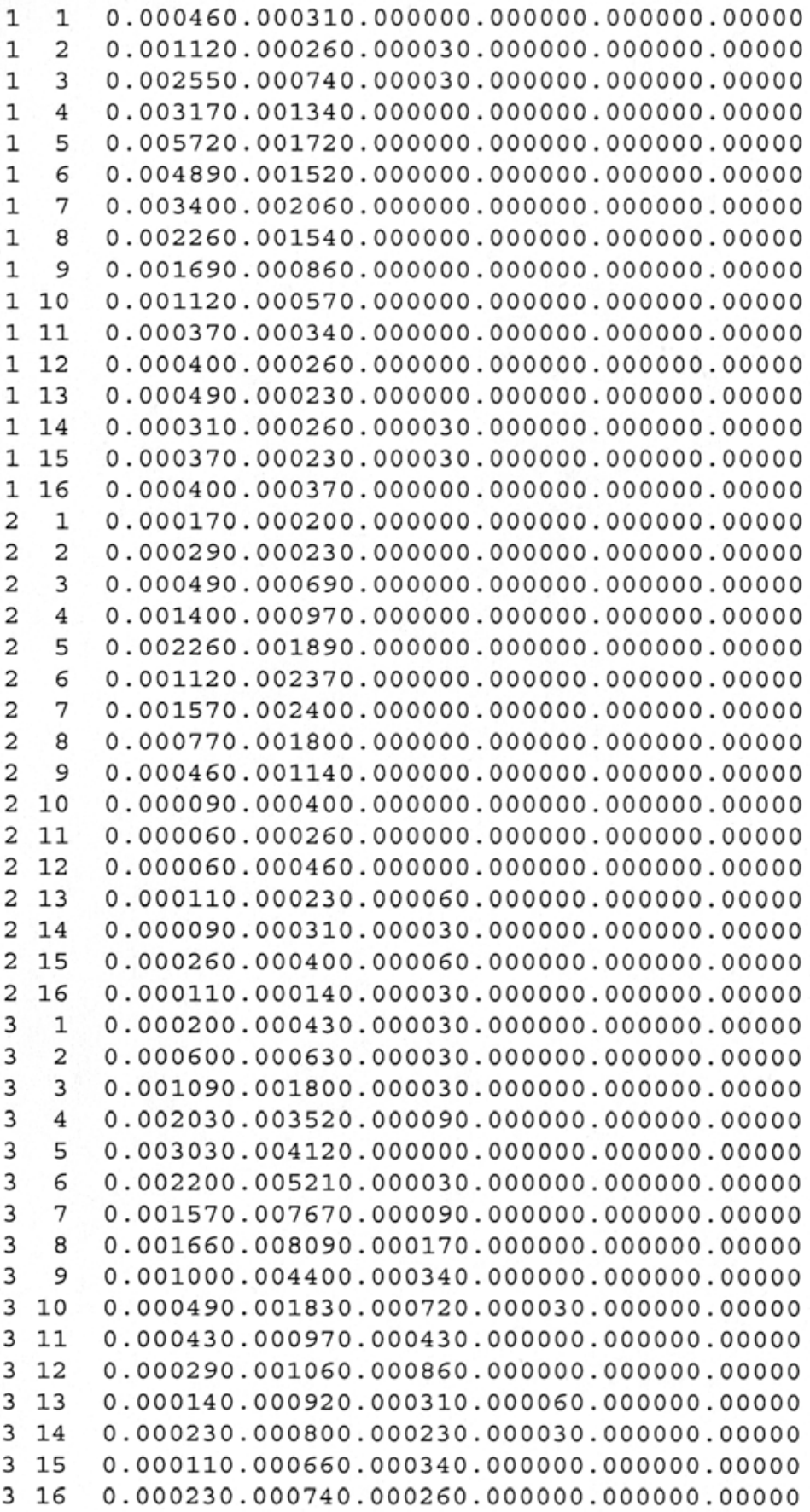


Table 7. (continued)

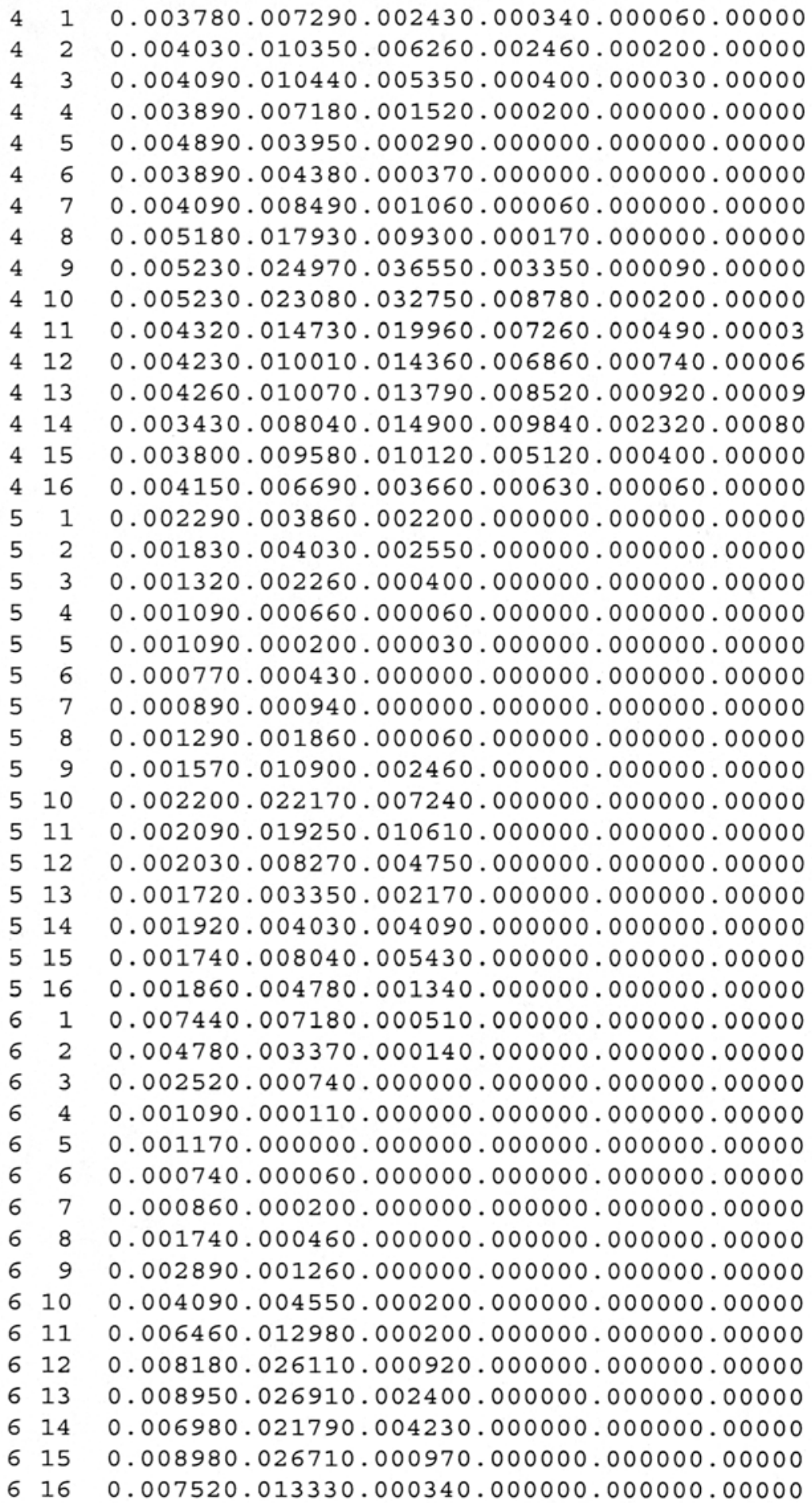


2004 LANL Radionuclide Air Emissions Report

Table 7. (continued)

CAP88 Input Data For 2003 TA-53 Meteorological Tower (98.6\% Data Completeness)

$\begin{array}{rrr}1 & 1 & 0.001180 .000230 .000030 .000000 .000000 .00000 \\ 1 & 2 & 0.002510 .000520 .000000 .000000 .000000 .00000 \\ 1 & 3 & 0.004500 .001530 .000000 .000000 .000000 .00000 \\ 1 & 4 & 0.004970 .003060 .000000 .000000 .000000 .00000 \\ 1 & 5 & 0.005250 .003460 .000000 .000000 .000000 .00000 \\ 1 & 6 & 0.003840 .002740 .000000 .000000 .000000 .00000 \\ 1 & 7 & 0.002770 .002370 .000000 .000000 .000000 .00000 \\ 1 & 8 & 0.002740 .001930 .000000 .000000 .000000 .00000 \\ 1 & 9 & 0.001240 .001530 .000000 .000000 .000000 .00000 \\ 1 & 10 & 0.001100 .000810 .000000 .000000 .000000 .00000 \\ 1 & 11 & 0.000660 .000640 .000000 .000000 .000000 .00000 \\ 1 & 12 & 0.000610 .000580 .000000 .000000 .000000 .00000 \\ 1 & 13 & 0.000520 .000230 .000000 .000000 .000000 .00000 \\ 1 & 14 & 0.000290 .000260 .000000 .000000 .000000 .00000 \\ 1 & 15 & 0.000430 .000320 .000000 .000000 .000000 .00000 \\ 1 & 16 & 0.001010 .000290 .000000 .000000 .000000 .00000 \\ 2 & 1 & 0.000290 .000230 .000000 .000000 .000000 .00000 \\ 2 & 2 & 0.000460 .000520 .000030 .000000 .000000 .00000 \\ 2 & 3 & 0.001270 .001820 .000030 .000000 .000000 .00000 \\ 2 & 4 & 0.001530 .003290 .000000 .000000 .000000 .00000 \\ 2 & 5 & 0.001410 .003230 .000000 .000000 .000000 .00000 \\ 2 & 6 & 0.000920 .002600 .000000 .000000 .000000 .00000 \\ 2 & 7 & 0.000870 .001820 .000000 .000000 .000000 .00000 \\ 2 & 8 & 0.000520 .002220 .000000 .000000 .000000 .00000 \\ 2 & 9 & 0.000350 .001410 .000030 .000000 .000000 .00000 \\ 2 & 10 & 0.000120 .000520 .000030 .000000 .000000 .00000 \\ 2 & 11 & 0.000090 .000550 .000000 .000000 .000000 .00000 \\ 2 & 12 & 0.000090 .000290 .000000 .000000 .000000 .00000 \\ 2 & 13 & 0.000030 .000460 .000000 .000000 .000000 .00000 \\ 2 & 14 & 0.000030 .000230 .000090 .000000 .000000 .00000 \\ 2 & 15 & 0.000140 .000260 .000060 .000000 .000000 .00000 \\ 2 & 16 & 0.000170 .000120 .000030 .000000 .000000 .00000 \\ 3 & 1 & 0.000400 .000550 .000230 .000000 .000000 .00000 \\ 3 & 15 & 0.000090 .000380 .000260 .000000 .000000 .00000 \\ 3 & 16 & 0.000350 .000460 .000170 .000000 .000000 .00000\end{array}$




\section{Table 7. (continued)}

\begin{tabular}{|c|c|c|}
\hline & & \\
\hline & 2 & 171800003410000350 \\
\hline & 3 & 005490.011260 .004560 .000430 .000 \\
\hline & 4 & .004620 .007850 .002280 .000350 .00 \\
\hline & 5 & .003810 .004330 .000690 .000030 .000000 \\
\hline & 6 & 0.002740 .004070 .000640 .000030 .0000 \\
\hline & 7 & 0.002280 .004390 .000900 .000140 .0 \\
\hline & 8 & 0.003120 .011230 .011580 .003060 .00 \\
\hline & 9 & $.002890 .018620 .037070 .015160 .0 \mathrm{C}$ \\
\hline & 10 & 0.002450 .017380 .039900 .022920 .00 \\
\hline & 11 & 0.002830 .014720 \\
\hline & 12 & 0.001910 .007710 .014380 .008230 .00 \\
\hline & 13 & 00912 \\
\hline & 14 & 0.002890 .006010 .009070 .004390$. \\
\hline & 15 & 03460 . \\
\hline & 16 & 0.004040 .006240 .003670 .000920 .0 \\
\hline & 1 & 02220 . \\
\hline & 2 & 0.005050 .007850$. \\
\hline & 3 & 0690. \\
\hline & 4 & 0.001880 .001360 .000030 .000000$. \\
\hline & 5 & 00030. \\
\hline & 6 & 0.000950 .001100$. \\
\hline & 7 & 0120.0 \\
\hline & 8 & 0.001390 .002800 .000660 .000000$. \\
\hline & 9 & 7620 . \\
\hline & 10 & 0.001880 .019520 .030580 .000000$. \\
\hline & 11 & 510.025060 .016460 .000000$. \\
\hline & 12 & 0.001990 .012760 .011200 .000000$. \\
\hline & 13 & 2250.011980 .009990 .000000$. \\
\hline & 14 & 0.002690 .008170 .003980 .000000$. \\
\hline & 15 & $\$ 130.006150 .002170 .000000$. \\
\hline & 16 & 0.005050 .007330 .002480 .00 \\
\hline & 1 & 0.003750 .001700 .000090 .00 \\
\hline & 2 & 0.004480 .001620 .000090 .000000$. \\
\hline & 3 & 0.004620 .001390 .000000 .00 \\
\hline & 4 & 0.004070 .000720 .000000 .0 \\
\hline & 5 & 0.002800 .000230 .000000$. \\
\hline & 6 & 0.002310 .000290 \\
\hline & 7 & 0.002510 .000810 .000000 .00 \\
\hline & 8 & 0.002940. \\
\hline & 9 & $0.003900 .003980 .000290 .000000 . c$ \\
\hline & 10 & 0.004040 .007130$. \\
\hline & 11 & 0.003490 .003380 .000490 .000000 .000000 .00 \\
\hline & 12 & 0.002800 .006470 .002080 .000000$. \\
\hline & 13 & 0.002660 .006500 .000900 .000000 .000000 .0000 \\
\hline & 14 & 0.003380 \\
\hline & 15 & 0.003550 .002080 .000060 .000000 .000000 .000 \\
\hline & 16 & $004270,001730.00003$ \\
\hline
\end{tabular}


Table 8. 40-61.94(b)(7) User-Supplied Data-Population Array

Estimated 2002 Population within $80 \mathrm{~km}$ of Los Alamos National Laboratory

\begin{tabular}{|c|c|c|c|c|c|c|c|c|c|c|c|c|c|c|c|c|c|c|}
\hline \multicolumn{19}{|c|}{ Distance from TA-53-LANSCE $(\mathrm{km})$} \\
\hline Direction & $0.8-1.0$ & $.01 .0-1$ & & $1.5-2.0$ & $02.0-2$. & & $2.5-3.0$ & $3.0-3.5$ & $3.5-4.0$ & $4.0-5.0$ & $5.0-6.0$ & $6.0-7.0$ & $7.0-8.0$ & $8.0-10$ & 10-20 & $20-30$ & $30-40$ & $40-80$ \\
\hline $\mathrm{N}$ & & 9 & 17 & & 56 & 27 & 53 & 82 & 94 & 139 & 0 & 0 & 0 & 0 & 16 & 97 & 1003 & 1483 \\
\hline NNW & & 7 & 17 & & 48 & 230 & 169 & 89 & 257 & 278 & 21 & 0 & 0 & 0 & 8 & 22 & 276 & 492 \\
\hline NW & & 9 & 17 & & 21 & 57 & 320 & 384 & 208 & 678 & 415 & 393 & 54 & 0 & 2 & 26 & 53 & 1076 \\
\hline WNW & & 0 & 0 & & 10 & 15 & 68 & 210 & 819 & 1047 & 1866 & 2613 & 723 & 0 & 0 & 33 & 38 & 3195 \\
\hline W & & 0 & 0 & & 0 & 0 & 0 & 0 & 96 & 163 & 0 & 0 & 0 & 0 & 9 & 80 & 356 & 175 \\
\hline WSW & & 0 & 0 & & 0 & 0 & 0 & 0 & 0 & 0 & 0 & 0 & 0 & 2 & 9 & 45 & 493 & 2909 \\
\hline SW & & 0 & 0 & & 0 & 0 & 0 & 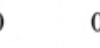 & 0 & 0 & 0 & 0 & 0 & 4 & 4 & 0 & 0 & 2932 \\
\hline SSW & & 0 & 0 & & 0 & 0 & 0 & 0 & 0 & 0 & 0 & 0 & 0 & 35 & 4 & 1048 & 1564 & 72580 \\
\hline $\mathrm{S}$ & & 0 & 0 & & 0 & 0 & 0 & 0 & 0 & 0 & 0 & 0 & 0 & 19 & 7 & 20 & 177 & 3953 \\
\hline SSE & & 0 & 0 & & 0 & 0 & 0 & 0 & 0 & 0 & 0 & 336 & 220 & 313 & 56 & 349 & 6351 & 3057 \\
\hline SE & & 0 & 0 & & 0 & 0 & 0 & 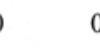 & 0 & 0 & 0 & 1546 & 3305 & 563 & 1 & 1160 & 81840 & 9164 \\
\hline ESE & & 0 & 0 & & 0 & 0 & 0 & 0 & 0 & 0 & 0 & 0 & 0 & 11 & 13 & 788 & 9029 & 3085 \\
\hline E & & 0 & 0 & & 0 & 0 & 0 & 0 & 0 & 0 & 0 & 0 & 2 & 1 & 1928 & 4593 & 447 & 490 \\
\hline ENE & & 0 & 0 & & 0 & 0 & 0 & 0 & 0 & 0 & 0 & 0 & 0 & 0 & 2309 & 5111 & 3953 & 3153 \\
\hline NE & & 7 & 10 & & 2 & 0 & 0 & 0 & 0 & 0 & 0 & 0 & 0 & 0 & 1298 & 15818 & 2690 & 6744 \\
\hline NNE & & 7 & 17 & & 53 & 8 & 38 & 32 & 25 & 24 & 0 & 0 & 0 & 0 & 15 & 2514 & 413 & 1047 \\
\hline
\end{tabular}


Table 9. 40-61.94(b)(7) User-Supplied Data—Radionuclide Emissions

\begin{tabular}{|c|c|c|c|c|c|}
\hline Stack ID & Nuclide $^{a}$ & Emission $(\mathrm{Ci})$ & Stack ID & Nuclide $^{\mathrm{a}}$ & Emission $(\mathrm{Ci})$ \\
\hline 03002914 & Th-228 & $1.23 \mathrm{E}-08$ & 03010222 & Th-234(p) & $1.61 \mathrm{E}-09$ \\
\hline 03002915 & Th-228 & $2.43 \mathrm{E}-08$ & 03010222 & $\mathrm{~Pa}-234 \mathrm{~m}(\mathrm{p})$ & $1.61 \mathrm{E}-09$ \\
\hline 03002919 & Am-241 & $1.67 \mathrm{E}-07$ & 16020504 & $\mathrm{H}-3$ (Gas) & $8.95 \mathrm{E}+01$ \\
\hline 03002919 & $\mathrm{Pu}-238$ & $1.66 \mathrm{E}-07$ & 16020504 & H-3 (HTO) & $5.04 \mathrm{E}+01$ \\
\hline 03002919 & Pu-239 & 8.54E-07 & 21015505 & $\mathrm{H}-3$ (Gas) & $2.71 \mathrm{E}+00$ \\
\hline 03002919 & Th-228 & $1.84 \mathrm{E}-08$ & 21015505 & H-3 (HTO) & $3.34 \mathrm{E}+02$ \\
\hline 03002919 & U-235 & $5.06 \mathrm{E}-09$ & 21020901 & H-3 (Gas) & $1.29 \mathrm{E}+01$ \\
\hline 03002920 & Am-241 & $8.17 \mathrm{E}-09$ & 21020901 & H-3 (HTO) & $2.86 \mathrm{E}+02$ \\
\hline 03002920 & Pu-239 & $3.02 \mathrm{E}-08$ & 16020504 & H-3 (Gas) & $8.95 \mathrm{E}+01$ \\
\hline 03002920 & U-234 & $2.26 \mathrm{E}-08$ & 48000107 & Ge-68 & 1.09E-04 \\
\hline 03002920 & U-235 & $1.78 \mathrm{E}-09$ & 48000107 & $\mathrm{Ga}-68(\mathrm{p})$ & $1.09 \mathrm{E}-04$ \\
\hline 03002923 & Am-241 & 2.70E-09 & 48000107 & $\mathrm{Rb}-86$ & 4.55E-06 \\
\hline 03002923 & $\mathrm{Pu}-238$ & $1.49 \mathrm{E}-08$ & 48000107 & Se-75 & $6.88 \mathrm{E}-06$ \\
\hline 03002923 & Th-230 & $1.54 \mathrm{E}-08$ & 48000107 & Th-230 & $6.94 \mathrm{E}-10$ \\
\hline 03002923 & U-234 & 8.61E-07 & 48000154 & ND & $0.00 \mathrm{E}+00$ \\
\hline 03002923 & U-235 & $3.14 \mathrm{E}-08$ & 48000160 & Se-75 & $5.30 \mathrm{E}-07$ \\
\hline 03002923 & U-238 & $3.16 \mathrm{E}-08$ & 48000160 & Th-230 & $1.54 \mathrm{E}-09$ \\
\hline 03002923 & Th-234(p) & $3.16 \mathrm{E}-08$ & 50000102 & Th-228 & $4.84 \mathrm{E}-08$ \\
\hline 03002923 & $\mathrm{~Pa}-234 \mathrm{~m}(\mathrm{p})$ & $3.16 \mathrm{E}-08$ & 50000102 & Th-230 & $2.15 \mathrm{E}-08$ \\
\hline 03002924 & Am-241 & 8.13E-09 & 50003701 & U-232 & $9.36 \mathrm{E}-09$ \\
\hline 03002924 & $\mathrm{Pu}-238$ & $1.15 \mathrm{E}-07$ & 50006903 & U-235 & $5.02 \mathrm{E}-11$ \\
\hline 03002924 & Pu-239 & $1.36 \mathrm{E}-08$ & 53000303 & $\mathrm{C}-11$ & $1.84 \mathrm{E}+00$ \\
\hline 03002924 & Th-228 & $6.79 \mathrm{E}-08$ & 53000303 & H-3 (HTO) & $6.30 \mathrm{E}-01$ \\
\hline 03002924 & U-234 & $1.79 \mathrm{E}-06$ & 53000702 & Ar-41 & $8.48 \mathrm{E}+00$ \\
\hline 03002924 & U-235 & $6.12 \mathrm{E}-09$ & 53000702 & As-72 & $2.21 \mathrm{E}-05$ \\
\hline 03002928 & Am-241 & $1.41 \mathrm{E}-08$ & 53000702 & As-73 & $1.34 \mathrm{E}-04$ \\
\hline 03002928 & $\mathrm{Pu}-238$ & $6.75 \mathrm{E}-07$ & 53000702 & $\mathrm{Be}-7$ & $1.29 \mathrm{E}-06$ \\
\hline 03002928 & Pu-239 & $1.86 \mathrm{E}-07$ & 53000702 & Br-76 & $1.84 \mathrm{E}-03$ \\
\hline 03002928 & U-234 & $7.75 \mathrm{E}-09$ & 53000702 & Br-77 & $2.24 \mathrm{E}-05$ \\
\hline 03002928 & U-235 & 2.06E-09 & 53000702 & $\mathrm{Br}-82$ & $1.51 \mathrm{E}-03$ \\
\hline 03002929 & ND & $0.00 \mathrm{E}+00$ & 53000702 & $\mathrm{C}-10$ & $8.10 \mathrm{E}-02$ \\
\hline 03002932 & Th-228 & $5.21 \mathrm{E}-07$ & 53000702 & $\mathrm{C}-11$ & $3.46 \mathrm{E}+03$ \\
\hline 03002932 & Th-230 & $3.67 \mathrm{E}-07$ & 53000702 & H-3 (HTO) & $2.68 \mathrm{E}+00$ \\
\hline 03002932 & Th-232 & 2.91E-07 & 53000702 & $\mathrm{Hg}-197 \mathrm{~m}$ & $2.18 \mathrm{E}-03$ \\
\hline 03002933 & ND & $0.00 \mathrm{E}+00$ & 53000702 & Hg-197(p) & $2.18 \mathrm{E}-03$ \\
\hline 03002937 & Th-228 & $3.58 \mathrm{E}-10$ & 53000702 & $\mathrm{~N}-13$ & $6.43 \mathrm{E}+01$ \\
\hline 03002944 & Pu-239 & $7.05 \mathrm{E}-09$ & 53000702 & $\mathrm{~N}-16$ & $2.81 \mathrm{E}-01$ \\
\hline 03002944 & U-234 & $2.65 \mathrm{E}-08$ & 53000702 & $\mathrm{Na}-24$ & 8.61E-06 \\
\hline 03002945 & Am-241 & $5.69 \mathrm{E}-09$ & 53000702 & O-14 & $4.75 \mathrm{E}+00$ \\
\hline 03002945 & Pu-239 & $1.10 \mathrm{E}-08$ & 53000702 & $\mathrm{O}-15$ & $8.99 \mathrm{E}+02$ \\
\hline 03002945 & Th-230 & $1.45 \mathrm{E}-08$ & 53000702 & Os-191 & $3.01 \mathrm{E}-05$ \\
\hline 03002946 & ND & $0.00 \mathrm{E}+00$ & 53000702 & $\mathrm{Se}-75$ & $3.44 \mathrm{E}-05$ \\
\hline 03010222 & Th-228 & $6.37 \mathrm{E}-10$ & 55000415 & U-234 & 3.07E-08 \\
\hline 03010222 & Th-230 & $3.76 \mathrm{E}-10$ & 55000415 & U-238 & $3.98 \mathrm{E}-08$ \\
\hline 03010222 & U-234 & $1.77 \mathrm{E}-08$ & 55000415 & Th-234(p) & $3.98 \mathrm{E}-08$ \\
\hline 03010222 & U-235 & $6.37 \mathrm{E}-10$ & 55000415 & $\mathrm{~Pa}-234 \mathrm{~m}(\mathrm{p})$ & $3.98 \mathrm{E}-08$ \\
\hline 03010222 & U-238 & $1.61 \mathrm{E}-09$ & & & \\
\hline
\end{tabular}


Table 9 (Continued)

\begin{tabular}{|r|l|c|}
\hline Stack ID & \multicolumn{1}{|c|}{ Nuclide $^{\mathrm{a}}$} & Emission (Ci) \\
\hline 55000416 & U-238 & $2.47 \mathrm{E}-08$ \\
55000416 & Th-234(p) & $2.47 \mathrm{E}-08$ \\
55000416 & Pa-234m(p) & $2.47 \mathrm{E}-08$ \\
\hline
\end{tabular}

\begin{tabular}{|r|c|c|}
\hline Stack ID & \multicolumn{1}{|c|}{ Nuclide $^{\mathrm{a}}$} & Emission (Ci) \\
\hline 55000416 & H-3 (Gas) & $3.80 \mathrm{E}+00$ \\
55000416 & H-3 (HTO) & $5.61 \mathrm{E}+00$ \\
\hline
\end{tabular}

NOTES:

${ }^{a}$ Radionuclides with the designator "(p)" are short-lived progeny in secular equilibrium with their parent radionuclide; e.g., Ga-68 (progeny) is in equilibrium with Ge-68 (parent).

Table 10. 40-61.94(b)(7) User-Supplied DataModeling Parameters for LANL Non-Point Sources-

\section{LANL Air Activation Sources}

\begin{tabular}{|c|c|c|c|c|c|}
\hline Source & Radionuclide & $\begin{array}{c}\text { Emission } \\
(\mathrm{Ci}) \\
\end{array}$ & $\begin{array}{l}\text { Area of Source } \\
\qquad\left(\mathrm{m}^{2}\right)\end{array}$ & $\begin{array}{c}\text { Distance to } \\
\text { LANL } \\
\text { Maximum } \\
\text { Dose Location } \\
\text { (m) }\end{array}$ & $\begin{array}{l}\text { Direction to } \\
\text { LANL } \\
\text { Maximum } \\
\text { Dose } \\
\text { Location }\end{array}$ \\
\hline \multirow[t]{2}{*}{ TA-53 Switchyard } & ${ }^{41} \mathrm{Ar}$ & $6.52 \mathrm{e}-01$ & 484 & 774 & NNE \\
\hline & ${ }^{11} \mathrm{C}$ & $1.57 \mathrm{e}+01$ & 484 & 774 & NNE \\
\hline \multirow[t]{2}{*}{ TA-53-1L Service Area } & ${ }^{41} \mathrm{Ar}$ & $2.63 \mathrm{e}+00$ & 1.0 & 943 & NNE \\
\hline & ${ }^{11} \mathrm{C}$ & $6.32 \mathrm{e}+01$ & 1.0 & 943 & $\mathrm{NNE}$ \\
\hline \multirow[t]{2}{*}{ TA-53-Isotope Production } & ${ }^{41} \mathrm{Ar}$ & $1.77 \mathrm{e}-03$ & na* & 1,230 & $\mathrm{NE}$ \\
\hline & ${ }^{11} \mathrm{C}$ & $4.24 \mathrm{e}-02$ & na* & 1,230 & $\mathrm{NE}$ \\
\hline TA-18 & ${ }^{41} \mathrm{Ar}$ & $9.10 \mathrm{e}-01$ & 31,400 & 3,894 & NNE \\
\hline
\end{tabular}

*Emissions from this source are released via a small ventilation stack. 
2004 LANL Radionuclide Air Emissions Report

Table 11. Environmental Data-Compliance Stations

2004 Effective Dose Equivalent (net in mrem) measured at air sampling locations around LANL.

\begin{tabular}{|c|c|c|c|c|c|c|c|c|c|}
\hline & Site Number and Name & H-3 & Am-241 & Pu-238 & Pu-239 & U-234 & U-235 & U-238 & $\begin{array}{c}\text { rounded } \\
\text { total } \\
\text { (mrem) }\end{array}$ \\
\hline 06 & 48th Street & 0.005 & 0.002 & -0.001 & 0.000 & 0.000 & 0.002 & 0.001 & 0.01 \\
\hline 08 & McDonalds & 0.015 & 0.001 & -0.001 & 0.001 & 0.003 & 0.001 & 0.003 & 0.02 \\
\hline 09 & Los Alamos Airport & 0.042 & 0.002 & -0.001 & 0.002 & 0.002 & 0.001 & 0.002 & 0.05 \\
\hline 10 & Eastgate & 0.034 & -0.001 & 0.000 & -0.001 & 0.003 & 0.000 & 0.000 & 0.04 \\
\hline 11 & Well PM-1 (East. Jemez) & 0.009 & -0.001 & -0.001 & 0.000 & 0.001 & 0.002 & 0.002 & 0.01 \\
\hline 12 & Royal Crest Trailer Court & 0.010 & 0.001 & -0.002 & -0.001 & 0.002 & 0.001 & 0.001 & 0.01 \\
\hline 13 & Rocket Park & 0.009 & 0.001 & 0.000 & -0.001 & 0.002 & 0.001 & 0.003 & 0.01 \\
\hline 14 & Pajarito Acres & 0.004 & 0.002 & -0.002 & 0.000 & 0.002 & 0.001 & 0.001 & 0.01 \\
\hline 15 & White Rock Fire Station & 0.005 & 0.003 & 0.000 & -0.002 & 0.003 & 0.001 & 0.002 & 0.01 \\
\hline 16 & White Rock Nazarene $\mathrm{Ch}$. & 0.016 & -0.001 & -0.001 & 0.005 & 0.005 & 0.000 & 0.001 & 0.03 \\
\hline 20 & TA-21 Area B & 0.035 & 0.004 & 0.002 & 0.003 & 0.004 & 0.001 & 0.002 & 0.05 \\
\hline 32 & County Landfill & 0.009 & 0.001 & 0.000 & 0.003 & 0.037 & 0.004 & 0.035 & 0.09 \\
\hline 60 & LA Canyon & 0.008 & 0.000 & -0.001 & 0.003 & 0.003 & 0.001 & 0.004 & 0.02 \\
\hline 61 & LA Hospital & 0.006 & 0.000 & -0.002 & -0.004 & 0.007 & 0.001 & 0.004 & 0.01 \\
\hline 62 & Crossroads Bible Church & 0.018 & 0.000 & -0.003 & 0.002 & 0.008 & 0.002 & 0.011 & 0.04 \\
\hline 63 & Monte Rey South & 0.005 & 0.000 & 0.000 & 0.000 & 0.003 & 0.002 & 0.002 & 0.01 \\
\hline 66 & Los Alamos Inn - South & 0.011 & 0.005 & -0.001 & 0.097 & 0.007 & 0.001 & 0.006 & 0.13 \\
\hline 67 & TA-3 Research Park & 0.005 & 0.003 & -0.002 & 0.000 & 0.022 & 0.004 & 0.019 & 0.05 \\
\hline 68 & Los Alamos Airport Road & 0.035 & 0.006 & -0.004 & 0.002 & 0.004 & 0.001 & 0.004 & 0.05 \\
\hline
\end{tabular}


2004 LANL Radionuclide Air Emissions Report

Table 12. Environmental Data-Compliance Stations

2004 Analytical Completeness and Air Sampler Operation Summary

\begin{tabular}{|l|l|r|r|r|r|r|r|r|r|}
\hline & & H-3 & Am-241 & Pu-238 & Pu-239 & U-234 & U-235 & U-238 & $\begin{array}{c}\text { percent } \\
\text { run time }\end{array}$ \\
\hline 06 & Site Number and Name & 100 & 100 & 100 & 100 & 100 & 100 & 100 & 99.5 \\
\hline 08 & McDonalds & 100 & 100 & 100 & 100 & 100 & 100 & 100 & 99.4 \\
\hline 09 & Los Alamos Airport & 100 & 100 & 100 & 100 & 100 & 100 & 100 & 100 \\
\hline 10 & Eastgate & 100 & 100 & 100 & 100 & 100 & 100 & 100 & 100 \\
\hline 11 & Well PM-1 (East. Jemez) & 100 & 100 & 100 & 100 & 100 & 100 & 100 & 99.6 \\
\hline 12 & Royal Crest Trailer Court & 100 & 100 & 100 & 100 & 100 & 100 & 100 & 99.8 \\
\hline 13 & Rocket Park & 100 & 100 & 100 & 100 & 100 & 100 & 100 & 99.8 \\
\hline 14 & Pajarito Acres & 100 & 100 & 100 & 100 & 100 & 100 & 100 & 99.7 \\
\hline 15 & White Rock Fire Station & 100 & 100 & 100 & 100 & 100 & 100 & 100 & 99.8 \\
\hline 16 & White Rock Nazarene Ch. & 100 & 100 & 100 & 100 & 100 & 100 & 100 & 99.8 \\
\hline 20 & TA-21 Area B & 100 & 100 & 100 & 100 & 100 & 100 & 100 & 99.4 \\
\hline 32 & County Landfill & 100 & 100 & 100 & 100 & 100 & 100 & 100 & 99.8 \\
\hline 60 & LA Canyon & 100 & 100 & 100 & 100 & 100 & 100 & 100 & 99.7 \\
\hline 61 & LA Hospital & 100 & 100 & 100 & 100 & 100 & 100 & 100 & 99.9 \\
\hline 62 & Crossroads Bible Church & 96 & 100 & 100 & 100 & 100 & 100 & 100 & 95.7 \\
\hline 63 & Monte Rey South & 100 & 100 & 100 & 100 & 100 & 100 & 100 & 99.8 \\
\hline 66 & Los Alamos Inn - South & 100 & 100 & 100 & 100 & 100 & 100 & 100 & 99.8 \\
\hline 67 & TA-3 Research Park & 92 & 100 & 100 & 100 & 100 & 100 & 100 & 99.8 \\
\hline 68 & Los Alamos Airport Road & 100 & 100 & 100 & 100 & 100 & 100 & 100 & 100 \\
\hline & & & & & & & & & \\
\hline
\end{tabular}


Table 13. LANSCE Monthly Assessments and Summary

\begin{tabular}{|c|c|c|}
\hline description & ESIDNUM & $\begin{array}{c}\text { Dose at East Gate } \\
\text { Receptor }\end{array}$ \\
\hline LANSCE-stack-January & 53000303 & $4.15 \mathrm{E}-05$ \\
\hline LANSCE-stack-February & 53000303 & 7.07E-05 \\
\hline LANSCE-stack-March & 53000303 & $7.46 \mathrm{E}-05$ \\
\hline LANSCE-stack-April & 53000303 & $1.57 \mathrm{E}-04$ \\
\hline LANSCE stack-May & 53000303 & na \\
\hline LANSCE stack-June & 53000303 & na \\
\hline LANSCE stack-July & 53000303 & na \\
\hline LANSCE stack-August & 53000303 & na \\
\hline LANSCE stack-September & 53000303 & na \\
\hline LANSCE-stack-October & 53000303 & na \\
\hline LANSCE-stack-November & 53000303 & na \\
\hline LANSCE-stack-December & 53000303 & na \\
\hline LANSCE-stack-PVAP ${ }^{*}$ & 53000303 & $3.17 \mathrm{E}-05$ \\
\hline LANSCE-Non-CAP88 Radionuclides ${ }^{*}$ & 53000303 & na \\
\hline LANSCE-stack-January & 53000702 & $9.72 \mathrm{E}-02$ \\
\hline LANSCE-stack-February & 53000702 & $1.82 \mathrm{E}-01$ \\
\hline LANSCE-stack-March & 53000702 & 5.32E-01 \\
\hline LANSCE-stack-April & 53000702 & $6.55 \mathrm{E}-01$ \\
\hline LANSCE stack-May & 53000702 & na \\
\hline LANSCE stack-June & 53000702 & na \\
\hline LANSCE stack-July & 53000702 & na \\
\hline LANSCE stack-August & 53000702 & na \\
\hline LANSCE stack-September & 53000702 & na \\
\hline LANSCE-stack-October & 53000702 & na \\
\hline LANSCE-stack-November & 53000702 & na \\
\hline LANSCE-stack-December & 53000702 & na \\
\hline LANSCE-stack-PVAP ${ }^{*}$ & 53000702 & $3.12 \mathrm{E}-04$ \\
\hline LANSCE-Non-CAP88 Radionuclides ${ }^{*}$ & 53000702 & $9.42 \mathrm{E}-04$ \\
\hline LANSCE-Fugitive Emissions - Switchyard & 530003 sy & $1.49 \mathrm{E}-02$ \\
\hline LANSCE-Fugitive Emissions - 1L Area & $5300071 \mathrm{~L}$ & $4.04 \mathrm{E}-02$ \\
\hline LANSCE-Fugitive Emissions - IP & 530007IP & $9.63 \mathrm{E}-06$ \\
\hline LANSCE Summary & & $1.52 \mathrm{E}+00$ \\
\hline
\end{tabular}

"Annual Value 
Table 14. 40-61.92 Effective Dose Equivalent at selected public locations.

\begin{tabular}{|c|c|c|c|c|c|}
\hline $\begin{array}{r}\text { Location } \\
\end{array}$ & Easting & Northing & $\begin{array}{c}\text { Nearest Airnet } \\
\text { Location }\end{array}$ & $\begin{array}{l}\text { AIRNET } \\
\text { number }\end{array}$ & $\begin{array}{c}\text { Air pathway } \\
\text { EDE } \\
(\mathrm{mrem})^{*}\end{array}$ \\
\hline Residence in White Rock & $1,654,280$ & $1,756,910$ & WR Fire Station & 15 & $2.54 \mathrm{E}-02$ \\
\hline Residence Near Urban Park & $1,618,400$ & $1,780,000$ & $48^{\text {th }}$ Street & 06 & $1.54 \mathrm{E}-02$ \\
\hline Residence on Fairway Drive & $1,618,602$ & $1,776,052$ & $48^{\text {th }}$ Street & 06 & $1.73 \mathrm{E}-02$ \\
\hline Los Alamos Apts Trinity Drive & $1,623,890$ & $1,775,900$ & Los Alamos Inn-S & 66 & $1.40 \mathrm{E}-01$ \\
\hline Los Alamos McDonald's & $1,626,450$ & $1,775,350$ & LA McDonald's & 08 & $4.66 \mathrm{E}-02$ \\
\hline Los Alamos Airport & $1,632,902$ & $1,776,247$ & Los Alamos Airport & 09 & $1.42 \mathrm{E}-01$ \\
\hline Tsankawi Visitor Center & $1,648,105$ & $1,758,380$ & Well PM-1 & 11 & $9.05 \mathrm{E}-02$ \\
\hline Royal Crest Trailer Court - West & $1,624,256$ & $1,773,065$ & Royal Crest Tlr. Crt. & 12 & $3.11 \mathrm{E}-02$ \\
\hline Royal Crest Trailer Court - East & $1,625,778$ & $1,772,955$ & Royal Crest Tlr. Crt. & 12 & $3.71 \mathrm{E}-02$ \\
\hline Residence near WR Rocket Park & $1,651,950$ & $1,755,300$ & Rocket Park & 13 & $2.71 \mathrm{E}-02$ \\
\hline Residence in Pajarito Acres & $1,650,770$ & $1,750,520$ & Pajarito Acres & 14 & $1.80 \mathrm{E}-02$ \\
\hline White Rock Fire Station & $1,653,580$ & $1,756,630$ & WR Fire Station & 15 & $2.59 \mathrm{E}-02$ \\
\hline White Rock Nazarene Church & $1,648,778$ & $1,754,676$ & WR Nazarene Ch. & 16 & 4.27E-02 \\
\hline Bandelier Fire Lookout & $1,635,700$ & $1,739,005$ & Bandelier $^{\dagger}$ & 17 & $1.68 \mathrm{E}-02$ \\
\hline Residence on Nambe Loop & $1,621,568$ & $1,776,046$ & Airport Road & 68 & $1.11 \mathrm{E}-01$ \\
\hline Ponderosa Campground & $1,608,575$ & $1,758,460$ & $\mathrm{TA}-49^{\dagger}$ & 26 & $2.17 \mathrm{E}-02$ \\
\hline County Landfill Office & $1,620,569$ & $1,774,763$ & County Landfill & 32 & $9.84 \mathrm{E}-02$ \\
\hline Los Alamos Ice Rink & $1,617,852$ & $1,775,692$ & LA Canyon & 60 & $2.59 \mathrm{E}-02$ \\
\hline Los Alamos Hospital & $1,620,200$ & $1,776,300$ & LA Hospital & 61 & $2.20 \mathrm{E}-02$ \\
\hline Crossroads Bible Church & $1,629,200$ & $1,776,000$ & Cross. Bible Church & 62 & $4.60 \mathrm{E}-02$ \\
\hline Residence on Monte Rey South & $1,647,976$ & $1,750,376$ & Monte Rey South & 63 & $2.52 \mathrm{E}-02$ \\
\hline Los Alamos Inn & $1,624,450$ & $1,775,300$ & Los Alamos Inn-S & 66 & $1.42 \mathrm{E}-01$ \\
\hline Research Park & $1,618,300$ & $1,774,600$ & TA-3 Research Park & 67 & $6.06 \mathrm{E}-02$ \\
\hline Business on DP Road & $1,630,445$ & $1,775,350$ & TA-21 Area B & 20 & $1.01 \mathrm{E}-01$ \\
\hline Business at East Gate (NNE sector) & $1,638,825$ & $1,774,097$ & East Gate & 10 & $1.58 \mathrm{E}+00$ \\
\hline Residence at East Gate (N sector) & $1,638,616$ & $1,774,231$ & East Gate & 10 & $1.20 \mathrm{E}+00$ \\
\hline Business at East Gate (NE sector) & $1,640,230$ & $1,774,090$ & East Gate & 10 & $7.86 \mathrm{E}-01$ \\
\hline
\end{tabular}

*Note, to allow for more meaningful comparisons, these doses do not include the estimated contribution from unmonitored point sources.

${ }^{\dagger}$ Note, these samplers are not part of the regular NESHAPs compliance network for LANL. 
Table 15. 61.92 Highest Effective Dose Equivalent Summary

\begin{tabular}{|c|c|c|c|}
\hline ESIDNUM & description & $\begin{array}{c}\text { Dose for Release } \\
\text { Site Receptor }\end{array}$ & $\begin{array}{c}\text { Dose at East Gate } \\
\text { Receptor }\end{array}$ \\
\hline 03002914 & CMR Stack & $2.18 \mathrm{E}-06$ & $1.80 \mathrm{E}-07$ \\
\hline 03002915 & CMR Stack & $2.82 \mathrm{E}-06$ & $3.02 \mathrm{E}-07$ \\
\hline 03002919 & CMR Stack & $2.34 \mathrm{E}-04$ & $2.20 \mathrm{E}-05$ \\
\hline 03002920 & CMR Stack & $1.02 \mathrm{E}-05$ & $9.37 \mathrm{E}-07$ \\
\hline 03002923 & CMR Stack & $5.26 \mathrm{E}-05$ & $6.16 \mathrm{E}-06$ \\
\hline 03002924 & CMR Stack & $1.50 \mathrm{E}-04$ & $1.55 \mathrm{E}-05$ \\
\hline 03002928 & CMR Stack & $1.15 \mathrm{E}-04$ & $1.42 \mathrm{E}-05$ \\
\hline 03002929 & CMR Stack & none & none \\
\hline 03002932 & CMR Stack & $1.46 \mathrm{E}-04$ & $1.76 \mathrm{E}-05$ \\
\hline 03002933 & CMR Stack & none & none \\
\hline 03002937 & CMR Stack & $6.35 \mathrm{E}-08$ & $5.28 \mathrm{E}-09$ \\
\hline 03002944 & CMR Stack & $3.25 \mathrm{E}-06$ & $3.19 \mathrm{E}-07$ \\
\hline 03002945 & CMR Stack & $5.62 \mathrm{E}-06$ & $5.59 \mathrm{E}-07$ \\
\hline 03002946 & CMR Stack & none & none \\
\hline 03010222 & Shops Addition Stack & $2.58 \mathrm{E}-06$ & $1.63 \mathrm{E}-07$ \\
\hline 16020504 & WETF Stack & $6.03 \mathrm{E}-03$ & $7.85 \mathrm{E}-04$ \\
\hline 18000001 & TA-18 Diffuse Emissions & $5.36 \mathrm{E}-05$ & $5.36 \mathrm{E}-05$ \\
\hline 21015505 & TSTA Stack & $1.20 \mathrm{E}-02$ & $7.27 \mathrm{E}-03$ \\
\hline 21020901 & TSFF Stack & $1.20 \mathrm{E}-02$ & $7.58 \mathrm{E}-03$ \\
\hline 48000107 & Radiochemistry Stack & $5.49 \mathrm{E}-07$ & $5.12 \mathrm{E}-08$ \\
\hline 48000107 & Radiochemistry Stack/non-CAP88 radionuclides & $6.50 \mathrm{E}-04$ & $5.50 \mathrm{E}-05$ \\
\hline 48000154 & Radiochemsitry Stack & none & none \\
\hline 48000160 & Radiochemistry Stack & $4.24 \mathrm{E}-08$ & $3.65 \mathrm{E}-09$ \\
\hline 50000102 & Waste Management Stack & $5.60 \mathrm{E}-06$ & $1.43 \mathrm{E}-06$ \\
\hline 50003701 & Waste Management Stack & none & none \\
\hline 50006903 & Waste Management Stack & 2.83E-09 & $6.12 \mathrm{E}-10$ \\
\hline 53000303 & LANSCE-Stack-Annual & $3.76 \mathrm{E}-04$ & $3.76 \mathrm{E}-04$ \\
\hline 530000 sy & LANSCE Fuguitive Emissions-Switch Yard & $1.49 \mathrm{E}-02$ & $1.49 \mathrm{E}-02$ \\
\hline 53000702 & LANSCE-Stack-Annual & $1.47 \mathrm{E}+00$ & $1.47 \mathrm{E}+00$ \\
\hline 53000702 & LANSCE-Stack/non CAP88 radionuclides & $9.42 \mathrm{E}-04$ & $9.42 \mathrm{E}-04$ \\
\hline $5300071 \mathrm{~L}$ & LANSCE Fuguitive Emissions-1L Service Area & 4.04E-02 & 4.04E-02 \\
\hline 530003IP & LANSCE Fuguitive Emissions-Isotope Production & $9.97 \mathrm{E}-06$ & $9.63 \mathrm{E}-06$ \\
\hline 55000415 & Plutonium Facility Stack & $6.16 \mathrm{E}-06$ & $8.22 \mathrm{E}-07$ \\
\hline 55000416 & Plutonium Facility Stack & $8.30 \mathrm{E}-04$ & $1.47 \mathrm{E}-04$ \\
\hline 99000000 & Unmonited Stacks-gross & $1.04 \mathrm{E}-01$ & $1.04 \mathrm{E}-01$ \\
\hline \multirow[t]{2}{*}{99000010} & Air-Sampler Net Dose & $1.25 \mathrm{E}-01$ & $3.62 \mathrm{E}-02$ \\
\hline & total & $1.78 E+00$ & $1.68 \mathrm{E}+00$ \\
\hline
\end{tabular}




\section{LANL Radionuclide Air Emissions Report}

\subsection{4(b) (9) Certification}

I certify under penalty of law that I have personally examined and am familiar with the information submitted herein and based on my inquiry of those individuals immediately responsible for obtaining the information, I believe that the submitted information is true, accurate, and complete. I am aware that there are significant penalties for submitting false information including the possibility of fine and imprisonment. See 18 U.S.C. 1001.

\section{(Signatures are on file.)}

Signature:

Date:

Edwin L. Wilmot, Owner

Manager

Los Alamos Site Office

National Nuclear Security Administration

U.S. Department of Energy

Signature:

Date:

Carolyn Mangeng, Operator

Associate Director for Technical Services

Los Alamos National Laboratory 


\title{
2004 LANL Radionuclide Air Emissions Report
}

\author{
Errata \\ 2003 LANL Radionuclide Emissions Report Errata as noted by D.P. Fuehne and K.W. Jacobson
}

As the Meteorology and Air Quality group transitioned to a new analytical lab in September 2003, a slight oversight occurred in reporting of emissions. In the fourth calendar quarter of 2003, Se-75 was detected as a released radionuclide from TA-48 building 1 (ES-7 stack) but this emission was not listed in the 2003 report. Also, from this same stack, the released amount of Ge-68 (and its radioactive daughter Ga-68) was greater than that which was stated in the 2003 report. This oversight did not affect the measured or reported emissions of our dominant radionuclide emissions types, gaseous mixed activation products, and tritium. This issue was documented in memorandum ENV-MAQ:04-382, dated November 18, 2004.

The following table shows the changed emissions (in Ci):

$\begin{array}{ccc}\text { Radionuclide } & \text { Activity (original) } & \text { Activity (corrected) } \\ \text { Se-75 } & \text { None } & 4.16 \mathrm{E}-07 \\ \text { Ge-68 } & 3.33 \mathrm{E}-04 & 3.62 \mathrm{E}-04 \\ \text { Ga-68 } & 3.33 \mathrm{E}-04 & 3.62 \mathrm{E}-04\end{array}$

Thus the dose to the receptor for TA- 48 building 1 changed from $1.55 \mathrm{e}-03$ mrem to $1.75 \mathrm{e}-03$ mrem. The LANL highest affected dose equivalent for 2003 remains unchanged at $0.65 \mathrm{mrem}$.

On November 23, 2004, the EPA Region 6 office was notified of the deficiency. At that time, EPA requested that this issue be documented in this 2004 report in lieu of issuing a revised 2003 report. Procedures have been revised to address this underreporting and to prevent its future reoccurrence. 


\section{References}

1. Los Alamos National Laboratory, “SWEIS Yearbook-2003” Los Alamos National Laboratory report, LA-UR04-6024 (available URL: http://library.lanl.gov/cgi-bin/getfile?LA-UR-04-6024.htm), 2004.

2. U.S. Department of Energy, "Site-Wide Environmental Impact Statement for Continued Operation of the Los Alamos National Laboratory," Vol. Summary, DOE/EIS - 0238, Jan 1998, Albuquerque, New Mexico (available URL: http://www.lanl.gov/orgs/pa/News/doerelease051198.html), Jan 1998.

3. K. W. Jacobson, S. Duffy, and K. Kowalewsky, "Population and Agricultural Data Arrays for the Los Alamos National Laboratory," Los Alamos National Laboratory report LA-13469-MS, (available URL: http://www.airquality.lanl.gov/pdf/AQReports/LA-13469-MS.pdf), 1998.

4. R. Sturgeon, “2004 Radioactive Materials Usage Survey for Point Sources,” Los Alamos National Laboratory report, LA-UR-05-4728, 2005.

5. Los Alamos National Laboratory, "Performance Requirements for Air Quality,” Air Quality Group Laboratory Implementation Requirement LIR 404-10-01.2 (available URL: http://policies.lanl.gov/pods/policies.nsf/ByCollectionEnvironment?OpenView\&count=5000), 2003

6. U.S. Environmental Protection Agency, Federal Register, Vol. 60, No. 107 (June 5, 1995).

7. U.S. Environmental Protection Agency, "The Clean Air Act Assessment Package-1988 (CAP-88): A Dose and Risk Assessment Methodology for Radionuclide Emissions to Air," Vol. 1: User's Manual, EPA/Washington, D.C. (1990).

8. Radiation Shielding Information Center, "CAP-88 Clean Air Act Assessment Package," Oak Ridge National Laboratory, Tennessee (1990).

9. Frank Marcinowski, Acting Director, Radiation Protection Division, "Criteria to Determine Whether a Leased Facility at Department of Energy (DOE) is Subject to Subpart H," Office of Radiation and Indoor Air, U.S. Environmental Protection Agency (March 26, 2001).

10. U.S. Department of Energy, "External Dose-Rate Conversion Factors for Calculation of Dose to the Public," DOE/ES-0070 (July 1988).

11. U.S. Department of Energy, "Internal Dose Conversion Factors for Calculation of Dose to the Public," DOE/EH-0071 (July 1988).

12. Keith F. Eckerman, Anthony B. Wolbarst, and Allan C. B. Richardson, Federal Guidance Report No. 11, "Limiting Values of Radionuclide Intake and Air Concentration and Dose Conversion Factors for Inhalation, Submersion, and Ingestion," Office of Radiation Programs, U.S. Environmental Protection Agency, Washington, D.C. (1988).

13 K. F. Eckerman and J. C. Ryman, Federal Guidance Report No. 12, "External Exposures to Radionuclides in Air, Water, and Soil Exposure-to-Dose Coefficients for General Application," U.S. Environmental Protection Agency, Washington, D.C. (1993).

14. Keith W. Jacobson, letter to Mr. George Brozowski, Radiation Program Manager, Multimedia Planning and Permitting Division U.S Environmental Protection Agency, Region VI (June 8, 2005).

15. U.S. Environmental Protection Agency, "National Emission Standards for Emissions of Radionuclides Other than Radon from Department of Energy Facilities," Code of Federal Regulations, Title 40, Part 61.90, Subpart $\mathrm{H}$ (1989). 
16. Bart Eklund, "Measurements of Emission Fluxes from Technical Area 54, Areas G and L," Radian Corporation report, Austin, Texas (1995).

17 Los Alamos National Laboratory, "Performance Assessment and Composite Analysis for Los Alamos National Laboratory Materials Disposal Area G,” Los Alamos National Laboratory report LA-UR97-85 (1997). 
This report has been reproduced directly from the best available copy. It is available electronically on the Web (http://www.doe.gov/bridge).

Copies are available for sale to U.S. Department of Energy employees and contractors from:

Office of Scientific and Technical Information P.O. Box 62

Oak Ridge, TN 37831

(865) 576-8401

Copies are available for sale to the public from: National Technical Information Service

U.S. Department of Commerce

5285 Port Royal Road

Springfield, VA 22161

(800) 553-6847 
Los Alamos NATIONAL LABORATORY EST. 1943 